San Jose State University

SJSU ScholarWorks

Master's Theses

Master's Theses and Graduate Research

Summer 2011

\title{
Optimizing energy savings from "Direct-DC" in U.S. residential buildings
}

Evangelos Vossos

San Jose State University

Follow this and additional works at: https://scholarworks.sjsu.edu/etd_theses

\section{Recommended Citation}

Vossos, Evangelos, "Optimizing energy savings from "Direct-DC" in U.S. residential buildings" (2011). Master's Theses. 4078.

DOI: https://doi.org/10.31979/etd.anue-uc9q

https://scholarworks.sjsu.edu/etd_theses/4078

This Thesis is brought to you for free and open access by the Master's Theses and Graduate Research at SJSU ScholarWorks. It has been accepted for inclusion in Master's Theses by an authorized administrator of SJSU ScholarWorks. For more information, please contact scholarworks@sjsu.edu. 


\title{
OPTIMIZING ENERGY SAVINGS FROM "DIRECT DC" IN U.S. RESIDENTIAL BUILDINGS
}

\author{
A Thesis \\ Presented to \\ The Faculty of the Department of Environmental Studies \\ San José State University \\ In Partial Fulfillment \\ of the Requirements for the Degree \\ Master of Science
}

by

Evangelos Vossos

August 2011 
(C) 2011

Evangelos Vossos

ALL RIGHTS RESERVED 
The Designated Thesis Committee Approves the Thesis Titled OPTIMIZING ENERGY SAVINGS FROM "DIRECT DC" IN U.S. RESIDENTIAL BUILDINGS

by

Evangelos Vossos

APPROVED FOR THE DEPARTMENT OF ENVIRONMENTAL STUDIES SAN JOSÉ STATE UNIVERSITY

August 2011

Dr. Rachel O’Malley

Department of Environmental Studies

Dr. Will Russell

Department of Environmental Studies

Dr. Karina Garbesi

Department of Geography and Environmental Studies, Cal State East Bay, and Lawrence Berkeley National Laboratory 


\section{ABSTRACT \\ OPTIMIZING ENERGY SAVINGS FROM "DIRECT DC” \\ IN U.S. RESIDENTIAL BUILDINGS \\ by Evangelos Vossos}

An increasing number of energy-efficient appliances operate on direct current (DC) internally, offering the potential to use DC power from renewable energy systems directly and avoiding the losses inherent in converting power to alternating current (AC) and back. This paper investigates that potential for net-metered residences with on-site photovoltaics (PV) by modeling the net power draw of the "direct-DC house" with respect to today's typical configuration, assuming identical DC-internal loads. The power draws were modeled for houses in 14 U.S. cities using hourly simulated PVsystem output and residential loads. The latter were adjusted to reflect a 35\% load reduction representative of the most efficient DC-internal technology based on an analysis of 32 electricity end-uses. The model tested the effect of climate, electric vehicle loads, electricity storage, and load shifting on electricity savings; a sensitivity analysis was conducted to determine how future changes in the efficiencies of power system components might affect savings potential. National average direct-DC savings of $5 \%$ were estimated for configurations without storage and $14 \%$ for configurations with storage. Load shifting did not have a significant positive effect on savings, and the electric vehicle reduced the incremental savings compared to the same house configuration without it. The estimated savings were affected by the power system and appliance conversion efficiencies but were not significantly influenced by climate. 


\section{ACKNOWLEDGEMENTS}

In my ventures as a graduate student, I have been fortunate to meet several people who have helped me broaden my horizons through guidance, inspiration, and friendship. Karina Garbesi, who in essence was my main advisor for this project, has offered me these gifts and is the person to whom I owe my biggest thanks for completing this thesis.

I would also like to thank Rachel O'Malley and Will Russell for their patience and support with this paper and especially for guiding me through the whole duration of this master's program from the beginning to the graduation process.

In addition, I would like to acknowledge Robert Van Buskirk for initiating this research, which was funded by the U.S. Department of Energy as part of the Direct DC Power Systems Project, as well as the following people for their important contributions to this work: Jonathon Taylor, Gabriel Burch, Hongxia Shen, and Mary James from the Lawrence Berkeley National Laboratory, Tony Lai from Delta Products Corporation, and Eric Fry from Real Goods Solar.

For all the rest and for this, and for the smile on my face whenever I see her, I want to thank Nat. 


\section{TABLE OF CONTENTS}

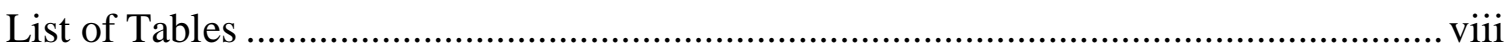

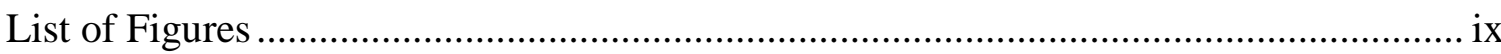

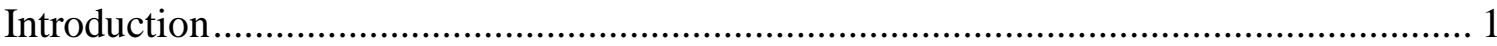

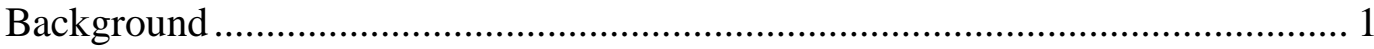

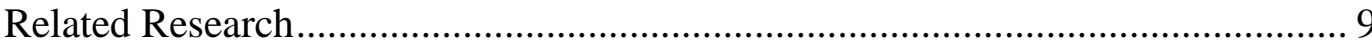

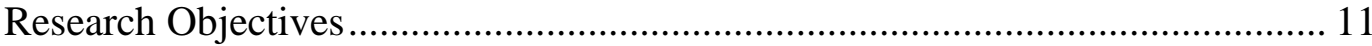

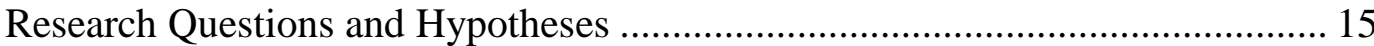

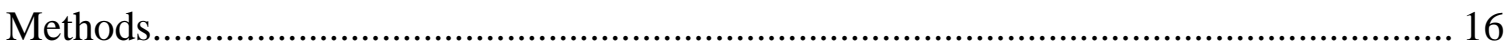

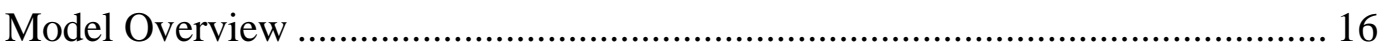

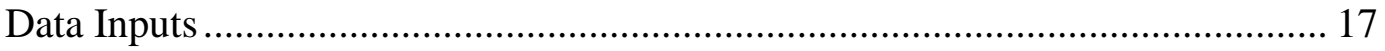

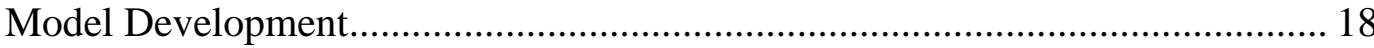

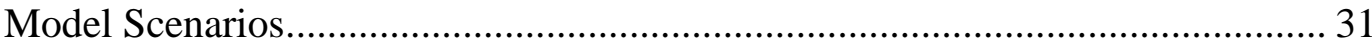

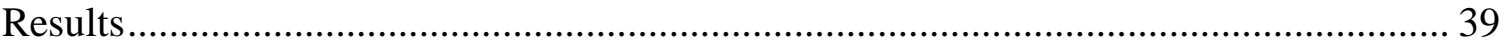

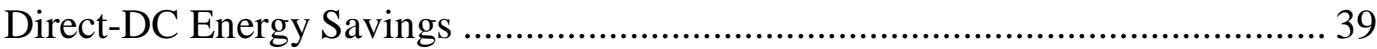

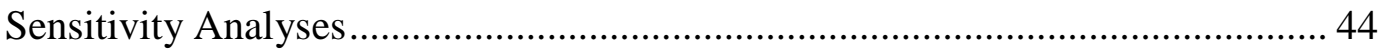

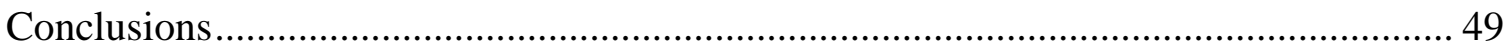

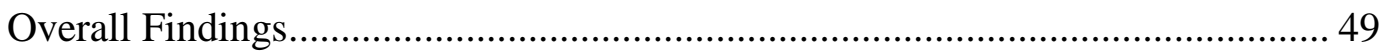

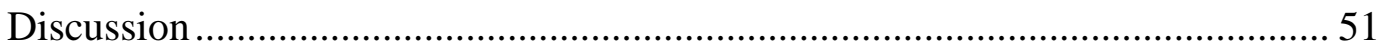

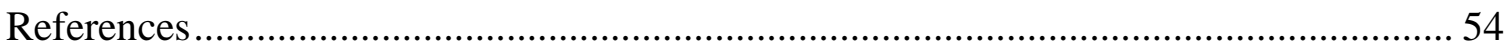

Appendix A: AC and DC House Power System Components ......................................... 59 
Appendix B: Efficient DC-Compatible Load ...

Appendix C: Modeling Calculations for Average Residential Load ............................... 68 


\section{LIST OF TABLES}

Table 1. Inputs Used in SAM to Generate the PV System Outputs for the 14 Cities.........18

Table 2. Power System Full-load Conversion Efficiencies ................................................25

Table 3. Residential Appliances Functions and Equivalent DC-Internal Technologies.....27

Table 4. Weighted Average Energy Savings Due to DC-internal Loads ............................28

Table 5. Weighted Average AC/DC Appliance Converter Efficiencies.................................31

Table 6. System Configurations for the Six Modeling Scenarios.........................................31

Table 7. Storage System Performance in the AC and DC Houses .....................................35

Table 8. Direct-DC Savings and Load Serviced Directly by PV .........................................41

Table 9. Direct-DC Savings and Load Serviced Directly by PV (Load Shifting) ...............43

Table 10. Direct-DC Savings for Improved Power System and Appliance

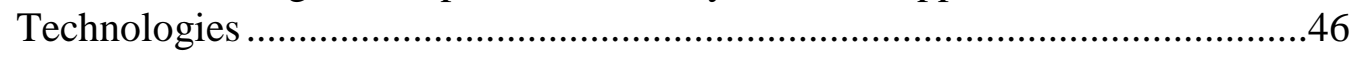

Table 11. Power System Components Part-load Efficiencies ..............................................47

Table A1. DC-DC Optimizers, Their Power Characteristics and Peak Efficiencies ..........63 


\section{LIST OF FIGURES}

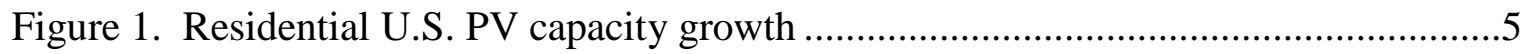

Figure 2. AC versus direct-DC distribution .......................................................

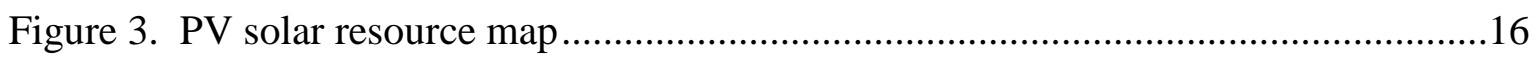

Figure 4. Average monthly diurnal load curves for Sacramento ...................................19

Figure 5. AC- and DC-house power system configuration........................................21

Figure 6. U.S. average residential electricity consumption by end-use in 2009 ..............26

Figure 7. AC/DC power converter efficiencies of AC-house appliances .........................30

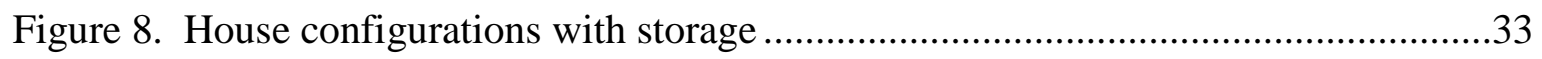

Figure 9. Relationship of maximum battery charging capacity to excess PV ...................34

Figure 10. Appliances energy savings versus direct-DC energy savings ........................39

Figure 11. Effect of added EV load on direct-DC savings ........................................44

Figure 12. Effects of part-load conditions to direct-DC savings ................................47

Figure A1. Grid-interactive inverter efficiency curve ..........................................61

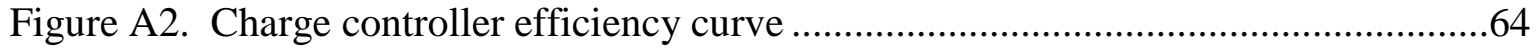

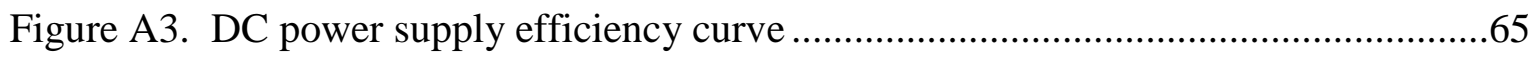




\section{Introduction}

A convergence of factors are driving recent interest in using the direct current (DC) from solar electric systems in its DC form to power electricity loads in buildings, rather than converting it to alternating current $(\mathrm{AC})$ first as is current practice. The new millennium has witnessed sustained and rapid growth in the adoption of rooftop solar electric systems and increased interested in advanced solar technology, as concerns over climate change have intensified. Net-metered photovoltaic power systems, which have dominated on-site renewable energy supply in the buildings sector, are a DC power source, as are batteries, which are the dominant energy storage technology used with such systems. An increasing fraction of the most efficient electric appliances operate internally on DC (George, 2006). This suggests that energy savings could be obtained by directly coupling DC power sources with DC appliances, thus avoiding DC-AC-DC power conversions. Recent demonstrations with commercial data centers have shown that significant energy savings can be achieved with DC power distribution delivered directly to DC loads, rather than utilizing AC power. This study assesses the relative energy savings of 'direct- $D C$ ' power for residential buildings.

\section{Background}

Historical review. The current electric distribution system is based on centralized production, high voltage transmission, and low voltage power delivery of AC. Each U.S. home connected to the electric grid is supplied with 120 or $240 \mathrm{~V}$ of AC at 60 Hz. However, the first power systems, designed by Thomas Edison, operated with DC. Edison's idea for electricity distribution was to develop small-scale power plants that 
would deliver power in small areas. A short while after the introduction of the DC distribution system, its AC counterpart was developed by George Westinghouse. AC was superior to DC because it enabled central generation and efficient long distance power transmission. Transmission losses over long distances were intolerably highly at the lowvoltages required by appliances. Westinghouse's invention of a low-cost AC transformer allowed power to be transmitted at high voltage and then transformed to low voltage for use in buildings. No comparable technology existed for DC power at the time (McNichol, 2006).

Renewed interest in Direct-DC. Recent trends call for a renewal of the AC versus DC debate, at least in certain applications:

Increased use of DC-based loads. An important factor that favors the use of DC is the growing number of electric appliances that operate internally on DC, and the fact that these new 'DC-internal' technologies tend to be more efficient than their AC counterparts (Garbesi, Vossos, \& Shen, 2011). "DC-internal” appliances include communication technologies and all consumer electronics, such as computers, telephones, televisions, compact fluorescent lighting with electronic ballast, light emitting diodes (LEDs), and efficient DC motors (Garbesi et al., 2011; Paajanen, Kaipia, \& Partanen, 2009). Fluorescent and LED lighting uses one-fourth of the power or less than the traditional incandescent lighting it is replacing in the residential and commercial sectors. Brushless DC permanent magnet motors can save 5-15\% of the energy used by traditional AC induction motors, and up to $30-50 \%$ in variable speed applications for pumping, ventilation, refrigeration, space cooling (Garbesi et al., 2011). DC-motor- 
driven heat pump technologies for water and space hearting can also displace conventional resistance heating with a savings of $50 \%$ or more.

Thus, three factors together suggest that DC-internal loads will continue to grow, and will probably grow rapidly: the intensified focus on energy efficiency due to climate change, the fact that new DC-internal technologies can be significantly more energy efficient than their conventional AC counterparts, and the fact that those technologies are capable of servicing virtually all building loads. Indeed, the fact that global residential electricity consumption by electronic appliances grew by about $7 \%$ per annum between 1990 and 2008 and is expected to increase by $250 \%$ by 2030 (International Energy Agency [IEA], 2009) makes continued intensive investment in energy efficiency an imperative.

In addition to DC-internal appliances, electric vehicles (EVs) and plug-in hybrid electric vehicles (PHEVs) are expected to constitute a rapidly growing pure DC load in the foreseeable future. Pure EV models currently available on the market include the Tesla Roadster and the Nissan LEAF (Nissan USA, 2011); many more models are anticipated (U.S. Department of Energy [DOE], 2010). The Chevrolet Volt PHEV-35, the first mass marketed PHEV in the U.S., was released for sale November 2010. Many other car companies plan PHEV releases in 2011 or 2012. Pike Research (Hurst \& Wheelock, 2009) projects rapid growth in world PHEV sales with a compound annual growth rate of more than $100 \%$ between 2010 and 2015 and that the U.S. will lead global sales in 2015 with more than one-third of the world market share. 
Rapid increase in U.S. residential PV. While DC power sources for residential applications include PV, DC micro-wind turbines, and micro-hydro, PV dominates building-sited renewable electricity generation. According to representatives of Real Goods, one of the largest and oldest vendors and installers of building-sited renewable energy systems and components in the U.S. (Malcomb, 2010), Real Goods sales and installations breakdown approximately as follows:

- $95 \%$ solar (>95\% grid-integrated),

- $3 \%$ micro-hydro, and

- $2 \%$ micro-wind.

Grid-connected PV installations have experience large and sustained growth in the U.S. since the start of the new millennium. As shown in Figure 1, between 2000 and 2009, U.S. residential PV installations exhibited an annual growth rate of about $20 \%$ with significantly higher growth rates in more recent years (Price \& Margolis, 2010). This growth was accompanied by a decline in the unsubsidized cost of PV installation of $3.2 \%$ per year from 1998 to 2009 (Barbose, Darghouth, \& Wiser, 2010). 


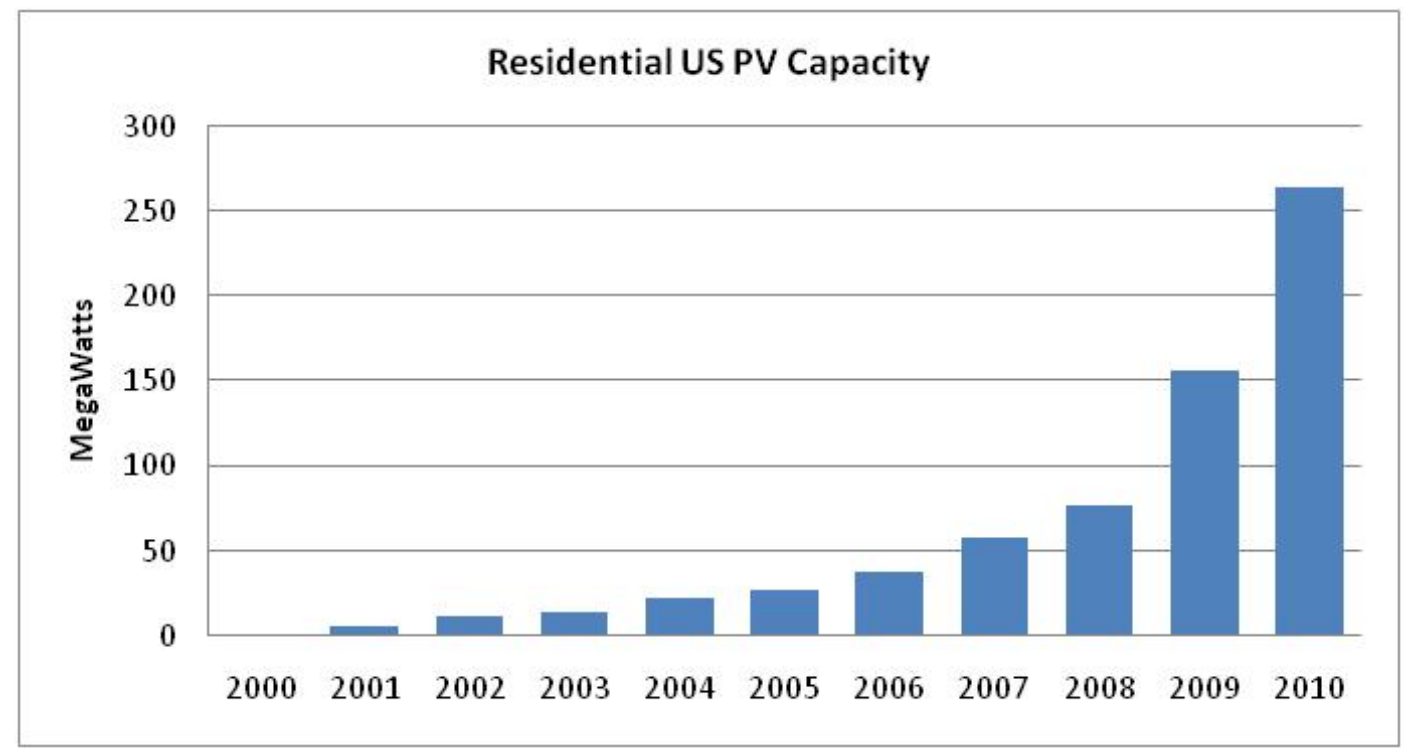

Figure 1. Residential U.S. PV capacity growth.

U.S. annual capacity additions of residential and commercial grid-connected PV in megawatts. Data sources: (Sherwood, 2010; Solar Energy Industries Association, 2010)

DC power standards, DC products, and demonstration projects. The EMerge

Alliance, an association of about 60 industry and research institute members, is guiding the development of DC technologies and standards in the U.S. (EMerge Alliance, 2011). It has already developed a $24 \mathrm{~V}_{\mathrm{DC}}$ standard for commercial buildings, and a $380 \mathrm{~V}_{\mathrm{DC}}$ standard for DC data center and telecom central office applications is currently underway. EMerge anticipates the development of residential standards as well. EMerge has dominated the debate on direct-DC in the U.S., hosting international meetings on the subject as part of the Darnell Group's Green Building Power Forum and Smart Grid meetings held for the past three years in the U.S. and Japan. These meetings have been the major U.S. forum for the evolving discussion of direct-DC power systems for buildings. 
The Green Building Power Forum meetings have demonstrated growing interest internationally in adopting the EMerge standards. The two main international players in direct-DC have been Japan and Korea. Japan's New Energy and Industrial Technology Organization (NEDO) has modeled the potential energy savings of direct-DC (Arthur D. Little is the consultant on that work) and has engaged Panasonic in the assessment and development of DC appliance prototypes. Japanese home electronics company Sharp is also testing DC-enabling technologies and equipment (Sharp, 2011) and has presented a replica of a solar-assisted, DC-powered home. Korea appears to be farthest along in direct-DC research and development, having completed a large residential DC demonstration project in 2009 (a 30KW project by Samsung C\&T Corp). This project showcases the integration of DC distribution and appliances with $22 \mathrm{~kW}$ of PV, $3 \mathrm{~kW}$ of wind power, and $200 \mathrm{~W}$ of fuel cell capacity, along with $22 \mathrm{kWh}$ of battery storage. This study claims only a modest $1.5-3 \%$ efficiency improvement resulting from direct-DC (Baek et al., 2011). These groups have been participating in meetings addressing DC voltage choice issues and desire a unified approach to DC standards.

In the U.S., new DC products that meet the EMerge standards are being developed for mainstream applications by member companies of the EMerge Alliance. These include both DC end-use products and products for DC power distribution and management. For example, Armstrong Ceiling Systems has created a ceiling suspension system called the DC Flexzone ${ }^{\mathrm{TM}}$ Grid (Armstrong, 2011) for low voltage DC distribution or power to ceiling mounted appliances. Nextek Power Systems has DC power 
controllers and Nextek and others have developed direct-DC lighting systems, fans, and controllers that can operate off the DC Flexzone Grid (Nextek Power Systems, 2010).

Others have been working on new DC technologies independent of EMerge: The California Lighting Technology Center at UC Davis is developing a DC light-emitting diode (LED) system powered by a PV array (K. Graeber, personal communication, June 2, 2010). The Center for Power Electronic Systems at the Virginia Institute of Technology is researching the development of a centralized or string-level maximum power point tracker (explained below) that interfaces directly with a residential PV system and provides $380 \mathrm{~V}_{\mathrm{DC}}$ power directly to the building loads (Lee, Boroyevich, Mattavelli, \& Ngo, 2010). It appears likely that all of these efforts will converge with the standards currently being developed by EMerge.

DC distribution in commercial data centers. Though not the subject of this paper, DC probably makes more sense in data centers than in any other type of facility. This is because the servers that provide the bulk of the load in data centers are inherently DC and require an uninterruptible power supply (UPS) in the form of an energy storage system that also operates on DC. In a typical data center, AC power is converted to DC at the UPS only to be switched back to AC before it is finally converted to DC at each server's power supply unit. A data center with DC distribution could eliminate these power conversions and lead to substantial energy savings.

A Lawrence Berkeley National Laboratory (LBNL) study (Ton, Fortenbery, \& Tschudi, 2007) addressed these energy savings by comparing the energy use of data centers with DC distribution to AC data centers with best-in-class components and 
concluded that a $7.2 \%$ decrease in energy use can be achieved with DC distribution. The same system yielded an estimated $28.2 \%$ efficiency gain compared to AC data centers with standard efficiency components.

Overall, these trends make a strong argument for investigating the potential benefits of directly coupling DC power sources with DC loads in residential buildings, because the intermediate DC-AC, AC-DC conversions losses could be avoided, as shown in Figure 2. However, because future houses are likely to continue to rely on grid power for backup for the foreseeable future, because the current cost of being entirely off-grid is much more costly and complex with its need for energy storage and or alternative supply, the reconfiguration of the power system for direct-DC would not be nearly as simple as implied by Figure 2 .

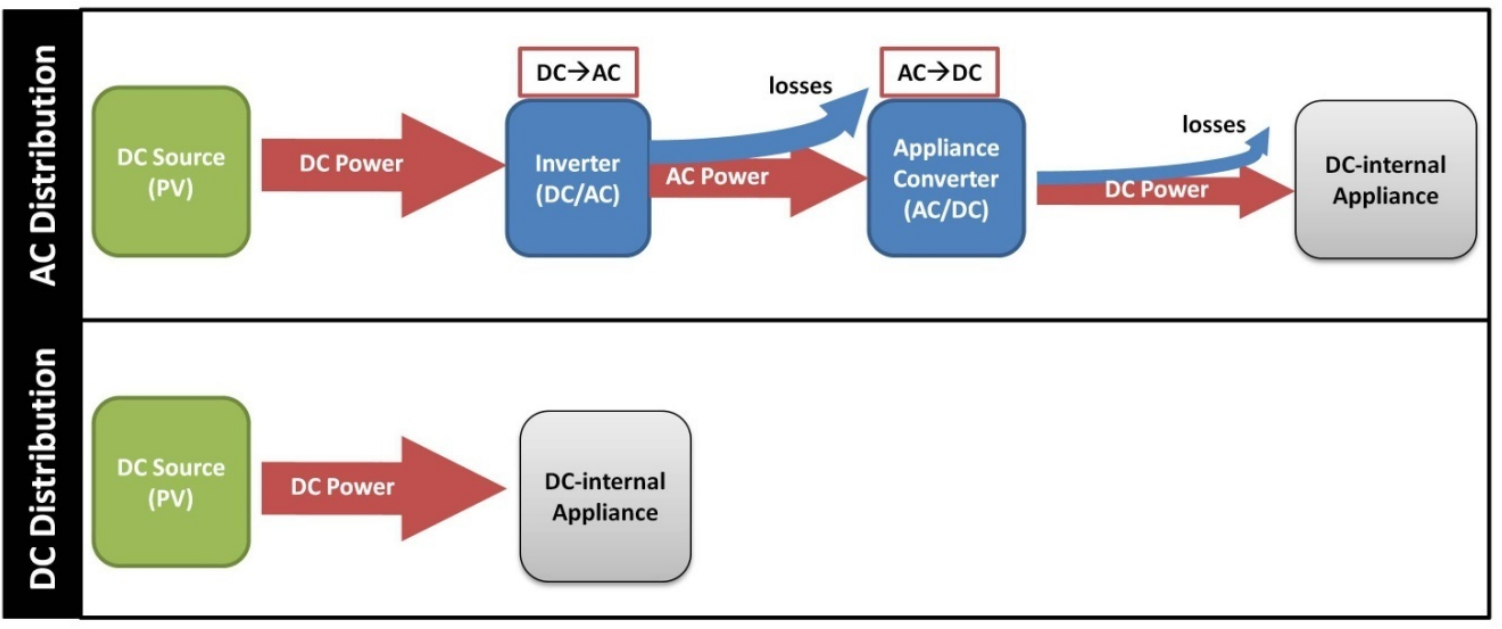

Figure 2. AC versus direct-DC distribution.

Comparison of power losses between a DC source and a DC-internal appliance for AC distribution and DC distribution. With AC distribution, power is lost due to the DC-AC and AC-DC conversions between the DC Source and the DC-internal appliance, whereas with DC distribution, power is sent directly to the load. 


\section{Related Research}

A number of studies have been published on the potential use of direct-DC in residential and commercial buildings, as well as DC microgrids (Ito, Zhongqing, \& Akagi, 2004; Kakigano, Miura, \& Ise, 2009), beyond the data center research described above. This section addresses those studies that focus on the power system configuration of residential and commercial buildings with direct-DC power distribution, and on studies and demonstration projects that determine direct-DC energy savings. These types of studies are summarized below:

Commercial buildings. Sannino, Postiglione, and Bollen (2003) evaluated a DC distribution system in a commercial facility with different supply voltages ranging from $48 \mathrm{~V}_{\mathrm{DC}}$ to $326 \mathrm{~V}_{\mathrm{DC}}$ and compared its energy losses to an $\mathrm{AC}$ power system at $230 \mathrm{~V}_{\mathrm{AC}}$ (line to ground). The authors modeled distribution losses for the tested systems and found that at the highest voltage level (326 Volts), DC distribution can be most beneficial, from both an economic and technical standpoint. Additionally, Nilsson (2005) created an office laboratory setup with four loads (a coffee maker, a computer and two fluorescent lamps) and evaluated the system's operating characteristics with DC distribution versus AC distribution. He concluded that a DC system could be preferable to an AC system in applications with many electronic loads, because DC distribution provided higher power quality and lower harmonics.

Residential buildings. A number of studies have targeted residential DC systems. The majority of studies have been purely analytical in nature, involving no demonstrations or laboratory measurements. A recent study by Savage, Nordhaus, and 
Jamieson (2010) estimated the potential energy savings that can be achieved by replacing appliance AC-to-DC converters with a more efficient centralized rectifier (that converts AC power coming from the grid to DC) and using DC distribution within the house to power DC-internal loads. The authors assumed 70-75\% efficiency for appliance AC-toDC converters and 90\% efficiency for the centralized rectifier and accounted for some efficiency improvements from switching from AC-powered to DC-internal appliances, such as refrigerators. The overall potential residential sector energy savings were estimated at $25 \%$, corresponding to a $3 \%$ U.S. load reduction. Hammerstrom (2007) created a model that compared DC versus AC distribution in a residential building with and without an on-site DC power source. He divided household appliances into eight different categories, in accordance with 2001 Energy Information Administration data, and assigned each category a power conversion loss for AC and DC distribution, assuming that conduction losses were equal for both the $\mathrm{AC}$ and $\mathrm{DC}$ system. He found that a residential DC power system connected to the AC grid by itself would not be advantageous unless a local DC energy source was available to feed power directly to the DC bus. In addition, Paajanen et al. (2009) ran a model that estimated the costs and energy use of residential power distribution for five scenarios, including AC distribution, hybrid AC and DC distribution, and DC distribution for various voltage levels. They concluded that for all scenarios that included DC distribution, energy efficiency and costs were improved. It should be mentioned that this study assumed high DC voltages (220V$750 \mathrm{~V}$ ) and power conversion efficiencies that favored DC distribution. In another study, Lee, Lee, and Lin (1999) acknowledged the increasing use of DC-internal home 
appliances and proposed a hybrid DC and AC power system that included energy storage and allowed for DC generation from solar cells. Engelen et al. (2006) calculated the conduction losses within a house with DC distribution at different line voltages and found that very small efficiency benefits can be achieved with DC distribution (depending on line voltages). Like Hammerstom, Engelen et al. do not recommend DC distribution in residential buildings unless on-site DC power generation is available.

While residential demonstration products are currently under discussion, Cetin et al. (2010) has produced the only published demonstration-type project for residential buildings. The researchers constructed a mini residential power system with a combination of a $5 \mathrm{~kW}$ PV array, a $2.4 \mathrm{~kW}$ fuel cell, and a $400 \mathrm{~W}$ wind turbine as DC energy sources supplying direct-DC to $12 \mathrm{~V}$ and $24 \mathrm{~V}$ DC-internal loads. The authors projected that the use of micro-DC distribution systems will be more widespread as the share of DC devices increases in the future.

\section{Research Objectives}

Like some earlier works, this modeling study quantifies the potential for residential energy savings that could be obtained by using DC power directly from on-site DC power sources. It also expands that work in important ways: it explores the means to optimize those savings, and it anticipates likely future changes in loads and power system configurations that could affect those savings. Specifically, this study addresses the following issues:

- It explicitly analyzes the potential impacts of using direct-DC in the context of grid-integrated, net-metered homes. 
- It quantifies the potential effect of climate conditions on direct-DC energy savings.

- It includes a detailed load analysis (investigating which products can be operated on direct-DC and the energy savings that could be obtained both from switching to DC-internal products and by avoiding the AC-to-DC conversion losses that are currently incurred by operating these products on AC power).

- It incorporates a sensitivity analysis on the effect of load variability vis-a-vis the impact of partial loads on power system component efficiencies. Prior studies assume that all power system components operate at constant full-load efficiency.

- It explores the impact of energy storage systems on direct-DC energy savings.

- It includes the impact of EV loads, a large anticipated future DC load.

- It investigates the potential benefits of shifting cooling loads earlier in the day to make the load more nearly synchronous to PV system output.

The following sections give additional justification for addressing net-metered homes, energy storage, EVs, and load shifting in the context of direct-DC residential distribution.

Net-metering. Because the grid provides low-cost backup power when sunlight is unavailable or insufficient to produce enough PV power to meet the load, more than 95\% of PV systems are grid-connected (EIA, 2010). Net metering makes grid-connected PV more economical by allowing periods of excess generation to be credited toward periods of deficit. State net-metering laws currently make this option available in 43 U.S. states (North Carolina Solar Center [NCSC] \& Interstate Renewable Energy Council [IREC], 2011). In a net-metered system, the PV system's power output is connected on 
the house side of the utility meter. The load consumes whatever power it needs, drawing first from the PV system if available and from the AC system to make up any deficit. At any instant, if there is an excess of PV power, it is sent to the grid driving the meter backwards. Depending on state net-metering rules and the available metering technology, time-of-use pricing may be used to determine the price or credit value of power drawn from or delivered to the grid.

If direct-DC has a future in residential and commercial power supply, for the foreseeable future it will be in net-metered grid-connected buildings. Not only is grid power far less costly than battery backup power, but the cost of battery storage per unit of load served goes up sharply as one tries to reach $100 \%$ of backup load requirements (Mulder, Ridder, \& Six, 2010). Thus, it is not expected that economically viable storage technologies will entirely displace the grid in this service. For these reasons, this project assumes that future DC products and power systems will be operating in net-metered grid-connected buildings.

Energy storage. While the capacity of net-metered grid-connected PV systems is increasing, the intermittence of the solar resource is a barrier to their future penetration (Denholm, Ela, Kirby, \& Milligan, 2010). A number of problems arise as penetration increases: If other local loads are unavailable to absorb excess PV, then local distribution systems and utility transformers, which were not designed for the purpose, would have to accommodate potentially large and variable reverse flows. At very high levels of penetration, utility base load capacity would be required to respond quickly to solar fluctuations. Because much base load supply, specifically nuclear and large coal plants, 
cannot respond instantaneously, excess power would have to be dissipated. According to Denholm and Margolis (2007), local battery storage for building-sited PV, if handled properly, could be used to buffer such fluctuations at lower cost than reconfiguring the utility generation and distribution system.

Ultimately, the decision to include energy storage in a future scenario that enables high PV penetration is one that depends on economic, environmental, and technological factors, the analysis of which exceeds the scope of this study. However, because residential energy storage systems are DC devices, and given the national and global interest in achieving high PV penetration, which necessitates storage, this study considers the implications of energy storage on potential energy savings from direct-DC.

Electric vehicles. EV and PHEV charging require the delivery of DC power to the vehicle's battery. While the current vision is to charge vehicles from rectified AC, EV charging would be more simply integrated into houses with DC distribution systems. The $380 \mathrm{~V}_{\mathrm{DC}}$ standard currently under development by the EMerge Alliance could accommodate EV charging; SAE International is currently developing a DC EV charging standard at a voltage range of 300-600 $\mathrm{V}_{\mathrm{DC}}$ (Ornelas, 2009). In addition, EV batteries could perhaps even serve as storage for building electricity, although currently an EV battery warranty will be void if it is used to provide power to any load except the EV.

Load shifting. Ignoring temporal changes in cloud conditions, PV output peaks at solar noon, but house loads usually peak during evening hours. If the load were more nearly synchronous with solar peak, more of the PV system output could be used directly by the DC loads. This raises the possibility that additional savings can be achieved with 
load shifting, which might, in theory, be implemented through the use of a Home Energy Management System.

\section{Research Questions and Hypotheses}

Based on the above research objectives and review of the related literature, this research specifically addressed the following question:

What is the electricity use of a net-metered house with DC distribution, with and without storage, compared to the electricity use of that house with AC distribution:

a. if both houses have the average residential load ${ }^{1}$ ?

b. if both houses include an EV?

c. if both houses include load shifting?

Hypotheses:

1. The DC distribution house will use less electricity compared to the same house with AC distribution for all scenarios tested.

2. Energy storage will increase the percent energy savings of the DC-distribution house compared to the AC-distribution house because stored energy delivered to loads will avoid the DC to AC and back to DC conversions.

3. Load shifting will increase the percent energy savings of the DC-distribution house compared to the AC-distribution house.

4. Direct-DC provides no advantage for EV charging if all EV charging is at night.

\footnotetext{
${ }^{1}$ The average residential load and modifications to it are detailed in the Methods chapter.
} 


\section{Methods}

\section{Model Overview}

A spreadsheet model was developed for a hypothetical house with a net-metered rooftop PV system. To test the potential effect of climate on direct-DC energy savings, the model was run for the average residence in 14 cities distributed across the contiguous United States. These cities, shown in Figure 3, were chosen because they were the only cities for which consistent residential load data were available in the desired format, as described below.

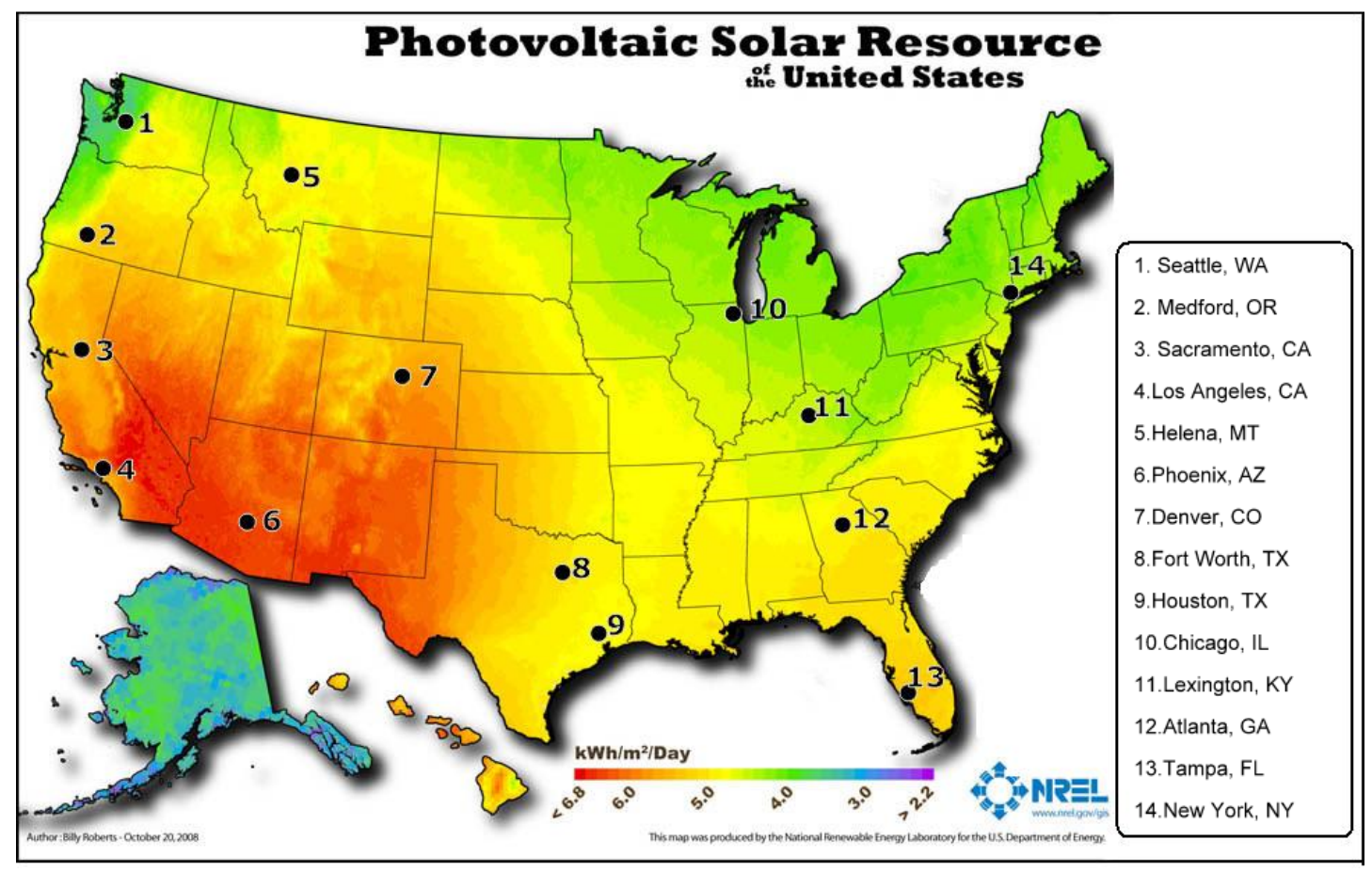

Figure 3. PV solar resource map.

Fourteen cities for which the model was run superimposed on a PV solar resource map of the United States. As can be seen on the map, the distribution of the sampled 14 cities is analogous to the distribution of the solar resource on U.S. soil. Source: (Roberts, 2008). Reproduced with permission from the author. 


\section{Data Inputs}

Load data. The model uses simulated average residential electricity load data from the Solar Advisor Model (SAM). The SAM simulation software, developed by the National Renewable Energy Laboratory (NREL), is an open access tool used widely by the renewable energy industry that provides performance and economic estimates for renewable energy projects. The load data for the 14 cities are provided as example characteristic loads and are climate-simulated for each hour of the year (in $\mathrm{kWh} / \mathrm{hr}$ for 8760 hours). It should be noted here that these are smooth load profiles characteristic of average loads, not of individual house loads, which are highly temporally variable. Because the smooth load assumption could affect both the instantaneous PV output that can be absorbed by the load and the system storage dynamics, this could affect the final energy savings estimates. It would therefore be beneficial to test load profiles that better simulate real house loads. Unfortunately, characteristic load profiles were not available for different parts of the country and it was beyond the scope of this study to develop them.

PV output. SAM (version 2010.11.9) was also used to generate hourly estimates of PV system output for the entire year ( 8760 hours) for each of the 14 cities using the modeling inputs indicated in Table 1. 
Table 1

Inputs Used in SAM to Generate the PV System Outputs for the 14 Cities

\begin{tabular}{lll}
$\begin{array}{l}\text { Input } \\
\text { parameters }\end{array}$ & $\begin{array}{l}\text { Input } \\
\text { value }\end{array}$ & \multicolumn{1}{c}{ Explanation } \\
\hline $\begin{array}{l}\text { PV system } \\
\text { DC rating }\end{array}$ & $1 \mathrm{~kW}^{\mathrm{a}}$ & $\begin{array}{l}\text { Although 1kW was used as each city's PV system capacity, the } \\
\text { actual capacity of each PV system was determined after scaling the } \\
\text { PV output to match the yearly electric load for the AC house. }\end{array}$ \\
\hline $\begin{array}{l}\text { PV array tilt } \\
\text { angle }\end{array}$ & $20^{\circ}$ & $\begin{array}{l}\text { The majority of residential PV systems are mounted on house roofs, } \\
\text { parallel to the plane of the roof. Most house roofs have a pitch that } \\
\text { ranges between 15 and 25 degrees. Also, a 20-degree tilt maximizes } \\
\text { summer energy production, which is preferable for utilities and } \\
\text { owners of net-metered PV systems. }\end{array}$ \\
\hline $\begin{array}{l}\text { Azimuth } \\
\text { angle }\end{array}$ & $180^{\circ}$ & $\begin{array}{l}\text { It was assumed that the PV systems have optimal (true south) } \\
\text { orientation for maximum performance. }\end{array}$ \\
\hline $\begin{array}{l}\text { Derate } \\
\text { factor }\end{array}$ & 0.85 & $\begin{array}{l}\text { The DC to AC derate factor accounts for losses due to ambient } \\
\text { conditions, inverter losses, mismatched modules, line losses, soiling } \\
\text { of the panels, and other factors. }\end{array}$ \\
\hline
\end{tabular}

a Note that the PV output was later scaled to accommodate a level of production that would result in zeronet electricity consumption for the conventional AC-House (as discussed below).

b The derate factor is immaterial for the modeling because it is a uniform scaling factor and SAM's PV output results were rescaled to effectively size the system for a zero-net electricity AC household. It is included here for completeness only.

\section{Model Development}

Distinguishing the cooling loads. Cooling loads were separated from non-

cooling loads in the modeling because of their varied large dynamic changes throughout the year, their distinct deviation from the base load, and because the cooling load was considered as the most significant candidate load to test for load shifting. In addition, DC house high-power loads were handled differently from low-power loads, and cooling is typically the most significant high-power load. Cooling is also a load that is influenced by solar irradiance and, therefore, by PV output.

Based on visual examination of the load data, cooling loads are clearly distinguished from non-cooling loads ( 
Figure 4). One can clearly see a common base load in the winter months. In warmer months a peak begins to grow in, which is the cooling load. The method used to estimate the cooling and the non-cooling loads is described below. Each city's 8760 hourly load values were converted to 12 x $24=288$ hourly load values for the average day of each month. The resulting average diurnal load curves for each month were plotted. An example is shown for Sacramento in Figure 4, which also includes the average PV output for June and January (represented with the dotted lines). According to the graph, six monthly load curves have clearly distinguishable evening cooling loads, while the load curves of the remaining six months are almost matching.

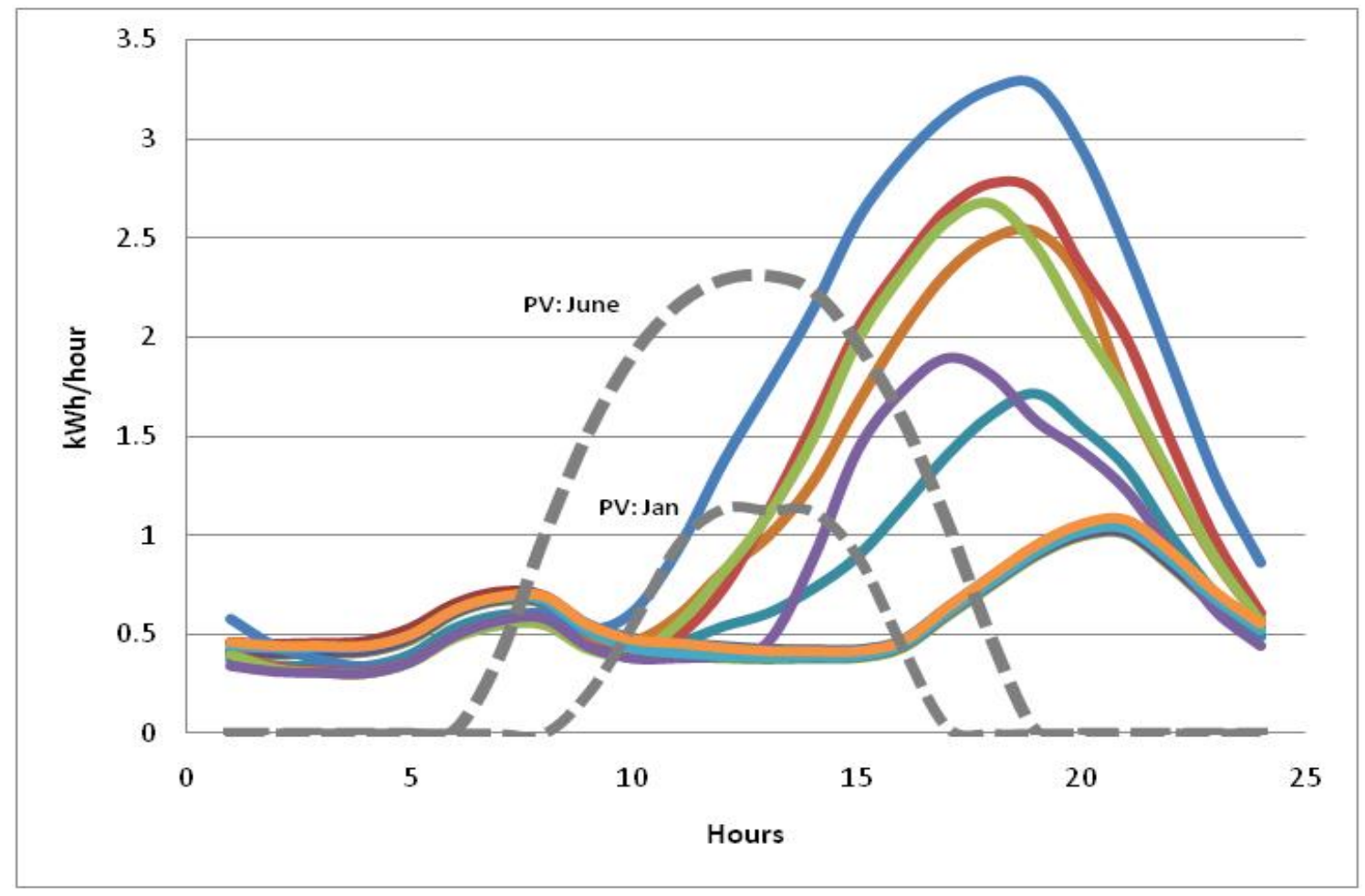

Figure 4. Average monthly diurnal load curves for Sacramento.

The monthly load curves have two characteristic peaks: A common, small peak during the morning hours (7am-9am) and a larger peak later in the day (3pm-8pm), which grows significantly in the summer months. This variance is attributed to the cooling load. It was assumed that the common load visible in the winter months is representative of the non-cooling load and that any excess is the cooling load. 
Modeling AC-house versus DC-house energy use. To quantify the potential energy savings of direct-DC, the model compares the energy conversion losses in two hypothetical houses (a house with AC distribution, called the AC-house, and a house with DC distribution called the DC-house). Specifically, in the AC-house, which constitutes the base case, all power is distributed inside the house in AC form to appliances that all accept $\mathrm{AC}$ power inputs. In the DC-house, all power is distributed inside the house in DC-form to appliances that accept DC power inputs, but are identical in every other way to their AC counterparts. That is, the AC appliances are assumed to be the DC-internal appliances with an AC-DC power converter (also called a power supply) on the input.

Figure 5 shows the modeling configuration for the AC-house (top) and DC-house (bottom). As discussed, the model incorporates separation of cooling and non-cooling loads for both house configurations. The non-cooling loads in the DC house are separated into high and low voltage loads. The low- and high-power voltages indicated are based on the existing and pending EMerge standards, respectively. 

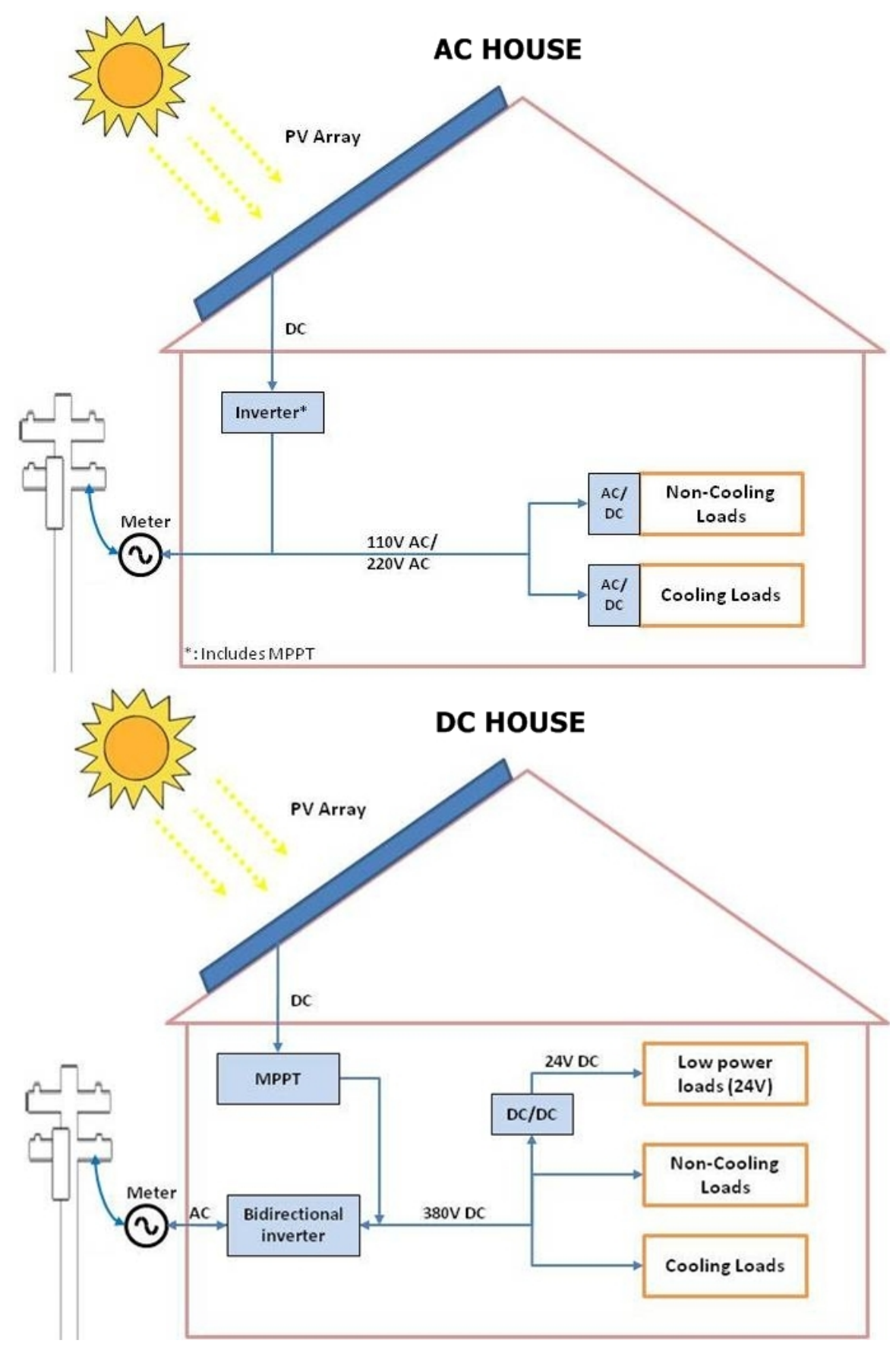

Figure 5. AC- and DC-house power system configuration.

Only components that generate, convert, and consume power are shown. The AC-house inverter (top) includes MPPT. The DC-house bidirectional inverter (bottom) does not include MPPT, because it is included separately. 
AC-house. In the AC house, DC power produced by the PV array is converted to AC by the inverter. That power is then distributed to the AC loads, supplying $240 \mathrm{~V}_{\mathrm{AC}} / 120 \mathrm{~V}_{\mathrm{AC}}$ to cooling and non-cooling loads, as shown in Figure 5. Any excess power produced by the PV system is sent to the grid via net-metering. The grid supports the house electricity needs when the PV system cannot provide the necessary power to the loads. Other PV system components include wiring, combiner boxes, DC and AC disconnects, etc. For simplicity, these components are not included in the figure. The arrows in the schematic show the possible direction of power within the distribution system.

DC-house. The DC-house power system configuration eliminates DC-AC-DC conversion losses to DC-internal appliances when adequate PV power is available to supply such appliances. However, it incurs other losses when AC grid backup power is used. Grid power must now be converted to DC to supply loads, and excess DC power must be inverted to $\mathrm{AC}$ for net metering. This is done with a bi-directional inverter, which combines a rectifier (AC/DC) and inverter (DC/AC). Even though the PV array no longer requires an inverter, it still needs a maximum power point tracker (MPPT) to provide the necessary constant voltage to the load and adjust the apparent load characteristics seen by the PV array to force it to operate at the maximum possible power output (Lee et al., 2010). MPPT is typically built into today's PV-system inverters and is therefore omitted from the AC-house schematic, but the power losses associated with the MPPT in the inverter are included in the modeling. Beyond that, most researchers envision that using direct-DC in residential and small commercial settings will require the 
use of high and low voltage DC (Baek et al., 2011; Cvetkovic et al., 2011): Low voltage (in the range of $12-48 \mathrm{~V}_{\mathrm{DC}}$ ) would be used for low-power loads like consumer electronics and lighting, to facilitate safer and easier handling and flexibility. High voltage $\left(200-400 \mathrm{~V}_{\mathrm{DC}}\right)$ would be used for high-power consumption devices like air conditioning systems and large appliances, and to distribute DC power throughout the house with fewer losses. Given that this would result in some mix of DC distribution at voltages both higher and lower than the standard 220 or $110 \mathrm{~V}_{\mathrm{AC}}$ and that this mix will depend on the house geometry, it is assumed that the DC-house has about the same resistance losses in wiring as does the AC-house. The chosen voltages for the DC-house reflect existing $\left(24 \mathrm{~V}_{\mathrm{DC}}\right)$ and pending $\left(380 \mathrm{~V}_{\mathrm{DC}}\right)$ EMerge Alliance standards for direct-DC. This configuration requires a DC/DC converter before the low-power loads (the figure shows one; in reality a number might be distributed to provide low-voltage power to buses in different regions of the house).

The characteristics of AC and DC loads for both AC- and DC-house configurations (including appliance converters) are discussed below.

PV sizing. The PV arrays in both houses are assumed to be identical, that is, to have the same DC output. The PV system in the AC house for each of the 14 cities is sized for annual zero-net electricity. Thus, over a one-year period the PV system's energy production (including inverter losses) equals the total annual AC-house electricity consumption.

Power system conversion efficiencies. Based on Figure 5, it is evident that any direct-DC energy savings depend inherently and sensitively on the conversion 
efficiencies of the AC versus DC power system components (shown in the figure as blue rectangles). A brief description of these components and a discussion of their efficiencies can be found in Appendix A. This section documents the modeling assumptions on power system component conversion efficiencies and justifies the choices. Because DC products are only now beginning to emerge in the market and are not yet produced for building-scale systems that include both high and low voltage DC, all power system component efficiencies were based on similar devices used for other purposes and are representative of high-end products on the market. Table 2 presents the values used in the model for the power system conversion efficiencies, as well as corresponding efficiency values found in recent literature. It should be noted that the efficiency values presented here have been reviewed and influenced by industry experts at the 2011 Green Building Power Forum, including makers of the new generation of DC power supplies for data centers and by EMerge Alliance members. 
Table 2

Power System Full-load Conversion Efficiencies

\begin{tabular}{|c|c|c|}
\hline Power System Component & $\begin{array}{c}\text { Model } \\
\text { Efficiency }\end{array}$ & Component Efficiency in Literature \\
\hline $\begin{array}{l}\text { PV Inverter (AC House), includes } \\
\text { MPPT }^{\mathrm{a}}\end{array}$ & $95 \%$ & $\begin{array}{l}\text { (Paajanen et al., 2009): 90\%, } \\
\text { (Zabalawi, Mandic, \& Nasiri, 2008): } \\
\text { 95\% }\end{array}$ \\
\hline DC-House Rectifier (meter $\rightarrow \mathrm{DC})^{\mathrm{b}}$ & $93 \%$ & $\begin{array}{l}\text { (Pang, Lo, \& Pong, 2006): 90\% } \\
\text { (Zabalawi et al., 2008): 95\% (Starke, } \\
\text { Tolbert, \& Ozpineci, 2008): 90\% }\end{array}$ \\
\hline DC-House Inverter (DC $\rightarrow$ meter $)^{b, c}$ & $97 \%$ & Not available in the market \\
\hline Charge controller or MPPT $^{\mathrm{d}}$ & $98 \%$ & See Appendix A \\
\hline $\begin{array}{l}\text { DC-House DC-DC Converter: } 380 \mathrm{~V} \\
-24 \mathrm{~V}^{\mathrm{b}}\end{array}$ & $95 \%$ & $\begin{array}{l}\text { (Paajanen et al., 2009): 90\%, } \\
\text { (Zabalawi et al., 2008): 95\% }\end{array}$ \\
\hline Battery (one way) ${ }^{\mathrm{e}}$ & $90 \%$ & $\begin{array}{l}\text { Varies depending on storage } \\
\text { technology and state of charge }\end{array}$ \\
\hline
\end{tabular}

a Typical of today's new PV-system string inverters.

${ }^{\mathrm{b}}$ Represents best models that could be built today, according to industry experts interviewed.

${ }^{c}$ Today's PV-system inverter minus the MPPT, which has estimated losses of $2 \%$.

d Typical of today's high-end charge controller efficiencies.

${ }^{\mathrm{e}}$ Consistent with findings by Stevens and Corey (1996).

Switching to DC-internal loads. To fairly compare the performance of the ACand DC-house, their loads needed to be identical except for their power input characteristics. Figure 6 shows a breakdown of the average U.S. residential electricity consumption by end-use for 2009, according to the Energy Information Administration (EIA). 


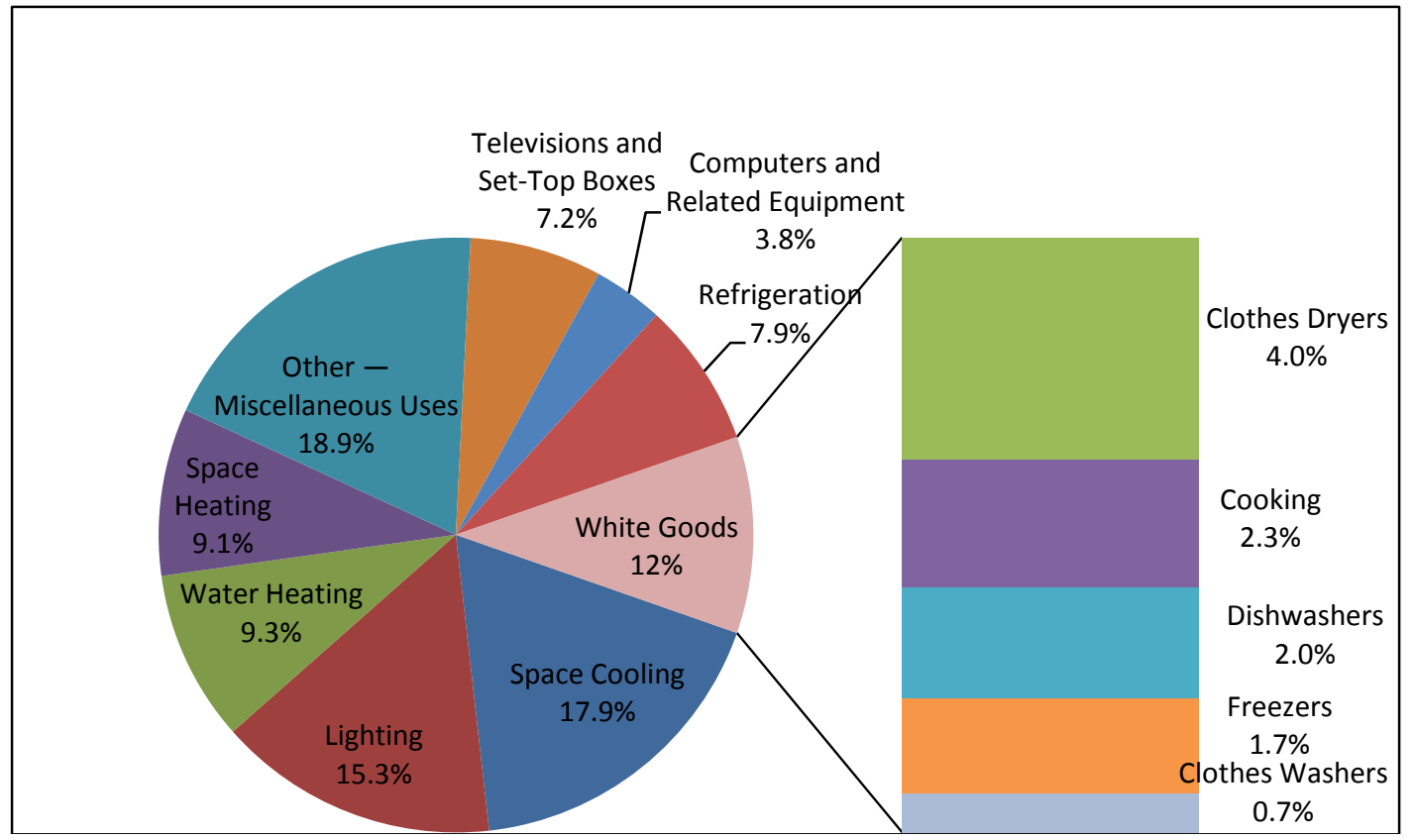

Figure 6. U.S. average residential electricity consumption by end use in 2009 . Source: (EIA, 2011)

In order to obtain the most current U.S. residential end-use consumption at as high a resolution as possible, EIA's National Energy Modeling System (NEMS) was used $^{2}$ (EIA, 2009). This resulted in an average annual U.S. residential electricity consumption for 2010 for 32 different appliances. The next step was to determine whether these appliances could operate on DC power. To achieve this, the internal

${ }^{2}$ Annually the U.S. DOE presents U.S. energy use forecasts in its Annual Energy Outlook (AEO), based on results from NEMS. Forecasts are necessary to estimate current year energy use because actual data are not yet available. While NEMS builds its estimates based on appliance level energy use data, only broader "end-uses" are reported in the AEO publications. To obtain energy use estimates at the appliance level for the residential sector, NEMS was run (the 2010 EIA release) using the AEO reference case assumption. 
functions of appliances were considered in terms of whether or not they could operate on

DC. Table 3 summarizes the results of this investigation.

Table 3

Residential Appliances Functions and Equivalent DC-Internal Technologies

\begin{tabular}{|c|c|c|c|c|}
\hline $\begin{array}{l}\text { Function } \\
\text { within } \\
\text { appliance }\end{array}$ & Appliance type & $\begin{array}{l}\text { Standard } \\
\text { technology }\end{array}$ & $\begin{array}{l}\text { DC-internal } \\
\text { best technology }\end{array}$ & $\begin{array}{l}\text { Energy savings } \\
\text { compared to } \\
\text { standard technology }\end{array}$ \\
\hline Lighting & $\begin{array}{l}\text { Incandescent, } \\
\text { fluorescent, LED }\end{array}$ & Incandescent & Electronic & $73 \%$ \\
\hline Heating & Heater & Electric resistance & $\begin{array}{l}\text { Heat pump } \\
\text { operated by } \\
\text { BDCPM (for } \\
\text { space and water) }\end{array}$ & $50 \%$ \\
\hline \multirow[t]{2}{*}{ Cooling } & \multirow{2}{*}{$\begin{array}{l}\text { Motor (including } \\
\text { compressor, } \\
\text { pump, and } \\
\text { motor-driven } \\
\text { fan) }\end{array}$} & \multirow{2}{*}{$\begin{array}{l}\text { Induction motor, } \\
\text { single-speed } \\
\text { compressor, pump, } \\
\text { and fan where } \\
\text { applicable }\end{array}$} & \multirow{2}{*}{$\begin{array}{l}\text { BDCPM } \\
\text { operating } \\
\text { variable speed }\end{array}$} & $30 \%-50 \%$ (VSD) \\
\hline & & & & $\begin{array}{l}\mathbf{5 - 1 5 \%} \text { (motor only } \\
\text { depending on size) }\end{array}$ \\
\hline $\begin{array}{l}\text { Mechanical } \\
\text { work }\end{array}$ & Motor & Induction motor & BDCPM & $\begin{array}{l}\mathbf{5 - 1 5 \%} \text { (depending on } \\
\text { size) }\end{array}$ \\
\hline Cooking & Electric cook top & Electric resistance & Induction cooker & $12 \%$ \\
\hline Computing & $\begin{array}{l}\text { Digital } \\
\text { technology }\end{array}$ & $\begin{array}{l}\text { Digital technology } \\
\text { already DC }\end{array}$ & Same & $\mathbf{0}$ \\
\hline
\end{tabular}

Energy savings of DC-internal loads. Many products like electric lighting, televisions, computers, and other electronics are already DC-internal and currently use AC-DC converters at their input stage. Resistance heating applications like electric space heaters and water heaters can use either AC or DC as input power. All other major applications use motors, compressors, pumps, or fans, all of which proved to be most efficient in their DC-internal form (Garbesi et al., 2011). Therefore, with energy 
efficiency guiding the selection of the hypothetical suite of appliances for both houses, it was decided to:

- replace all non-DC compatible equipment with DC-internal models currently on the market;

- replace electric resistance heating applications with DC-driven heat pump technologies where applicable models exist (electric water heaters, electric driers, electric furnaces); and

- replace all incandescent lights with electronic (fluorescent or LED)

This suite of appliances constitutes the efficient DC-compatible load assumed for both the AC- and DC-house load modeling. For a detailed presentation of the 32 house appliances considered, the assumed replacement DC-internal technology (if applicable), and the estimated energy savings that would be obtained by switching to efficient DCinternal appliances, see Appendix B. Note that the model actually uses a synthesis of the results of this analysis. Specifically, the weighted average of cooling and non-cooling load energy savings was determined that would be obtained if DC-internal technology operating on AC power was used. Thus, the results of the analysis presented in Appendix B are summarized in Table 4.

Table 4

Weighted Average Energy Savings Due to DC-internal Loads

\begin{tabular}{lc}
\hline Load type & Energy savings \\
\hline Cooling load & $37 \%$ \\
\hline Non-cooling load & $33 \%$ \\
\hline
\end{tabular}


To be consistent across all end-uses, in every case current electric loads were assumed to be the most efficient DC-internal technologies currently on the market. In every case, this resulted in a substantial increase in energy efficiency with overall energy savings of about $35 \%$ (depending on cooling load fraction) relative to current residential loads. So, in the case of lighting, even though incandescent lighting is DC compatible, it is not nearly as efficient as electronic ballast fluorescent and LED lighting, which are DC-internal and far more efficient. Similar, electric resistance heating (for space and water heating) was assumed to be replaced by heat pump heating operated with variable speed brushless DC motors.

Low-power loads. According to the power system topology of the DC-house, certain loads are powered at $24 \mathrm{~V}_{\mathrm{DC}}$. These loads include lighting and consumer electronics. Based on the total yearly energy consumption of these loads, shown in Appendix $\mathrm{B}$, the fraction of non-cooling loads powered at $24 \mathrm{~V}_{\mathrm{DC}}$ is $43 \%$.

AC-DC appliance conversion efficiencies. Because the appliances in both houses were assumed to be DC-internal, each AC-House appliance was assumed to have an AC-DC converter appropriate to the power consumption of the appliance. The conversion efficiencies of the AC-house AC/DC appliance converters were estimated using external power supply (EPS) data from the Energy Star database and $115 \mathrm{~V}$ and 230V EPS data from the 80 plus $^{3}$ database. Figure 7 shows the compiled efficiencies versus EPS power output from these two data sets. It should be noted that the power

\footnotetext{
${ }^{3}$ The 80plus power supply efficiency data correspond to desktop computers and servers typically used in data centers.
} 
supplies included in the Energy Star and the 80plus program are the most efficient on the market. Standard power supply efficiencies range from about $70 \%$ to $75 \%$ (Ton et al., 2007), whereas the power supply efficiencies plotted in Figure 7 range from about $85 \%$ to $95 \%$.

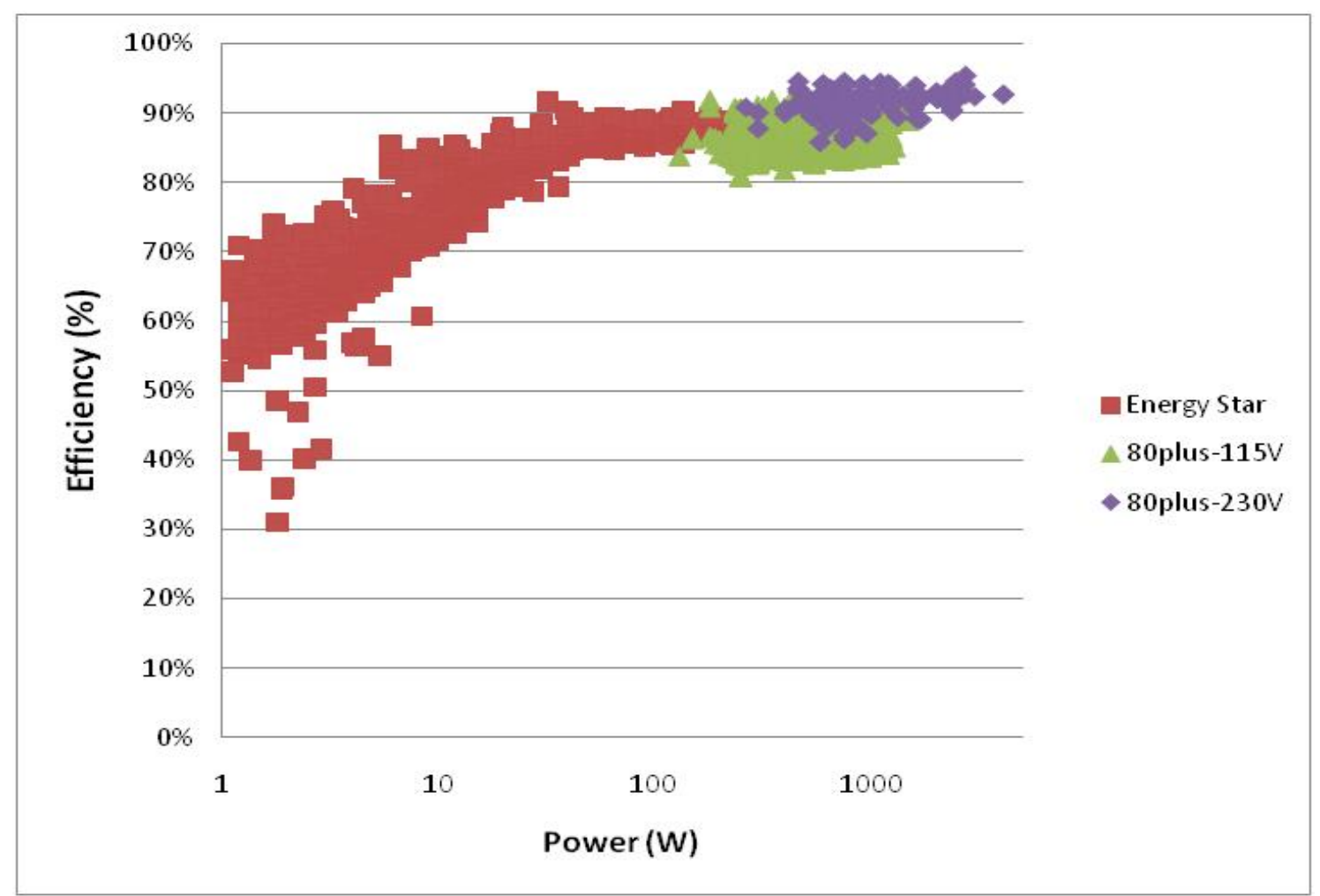

Figure 7. AC/DC power converter efficiencies of AC-house appliances. Sources: (Ecos, 2010; Star, 2010)

Similar to Table 4 above, the weighted average AC/DC appliance converter efficiencies for cooling and non-cooling loads respectively are shown in Table 5. See Appendix B for the appliance AC/DC converter efficiencies assumed for each of the 32 house appliances. 
Table 5

Weighted Average AC/DC Appliance Converter Efficiencies

\begin{tabular}{lc}
\hline Load Type & AC/DC appliance converter efficiency \\
\hline Cooling load & $90 \%$ \\
\hline Non-cooling load & $87 \%$ \\
\hline
\end{tabular}

\section{Model Scenarios}

Overview of system configurations. To compare the energy use of the ACversus the DC-house and to test implications of storage, load shifting, and EV, the following system configurations were considered, as presented in Table 6 . Note that for every system configuration, the AC-house remains identical to the DC-house, except for the power system components and the form (AC or DC) in which power is delivered to the loads. Thus, both houses are assumed to have identical electricity storage systems in configurations where storage is considered (1b, 2b, and $3 b)$, the same EVs in configurations $3 \mathrm{a}$ and $3 \mathrm{~b}$, and the same load shifting mechanisms in configurations $2 \mathrm{a}$ and $2 b$.

Table 6

System Configurations for the Six Modeling Scenarios

\begin{tabular}{|c|c|}
\hline Without electricity storage & With electricity storage \\
\hline 1a. Average residential load* & 1b. Average residential load \\
\hline 2a. Shifted average residential load & 2b. Shifted average residential load \\
\hline 3a. Average residential load \& EV & 3b. Average residential load \& EV \\
\hline
\end{tabular}


Configurations with storage. Battery storage was included in both houses ${ }^{4}$. Battery efficiency was assumed to be $90 \%$ one-way ( $81 \%$ round-trip), as shown in Table 2. Although real-world batteries have efficiencies that vary depending on various factors, including state of charge, ambient temperature, and battery age, for the purposes of the study these factors were overlooked. In both house configurations, the charge controller, which includes MPPT, regulates current to and from the batteries. The battery voltage while assumed to be $380 \mathrm{~V}_{\mathrm{DC}}$ in both the $\mathrm{AC}$ - and $\mathrm{DC}$-house, it is immaterial to the modeling. The storage system is assumed to be charged only by excess PV power, which is instantaneous PV power exceeding total load capacity, but not by rectified grid power. This is done because storage is being used to maximize PV penetration by buffering the PV grid from large output spikes. Stored electricity is used to power loads when PV output is not sufficient to supply the load. When both the PV array and the battery do not have enough power to supply the loads, electricity is drawn from the grid. In addition, when the battery reaches its maximum charging capacity, excess PV power is sent to the grid via net-metering. The AC-house inverter is bidirectional, as is the norm for modern grid-interactive inverters with battery back-up (see Appendix A for details).

Figure 8 shows system configuration $3 \mathrm{~b}$ - Average residential load \& $E V$ (with storage) for both houses. The EV configurations are discussed below and are shown here for completeness.

\footnotetext{
${ }^{4}$ Because the model compares energy losses between the AC-house and the DC-house, only the storage system efficiency affects the modeling results and not the assumed storage technology.
} 

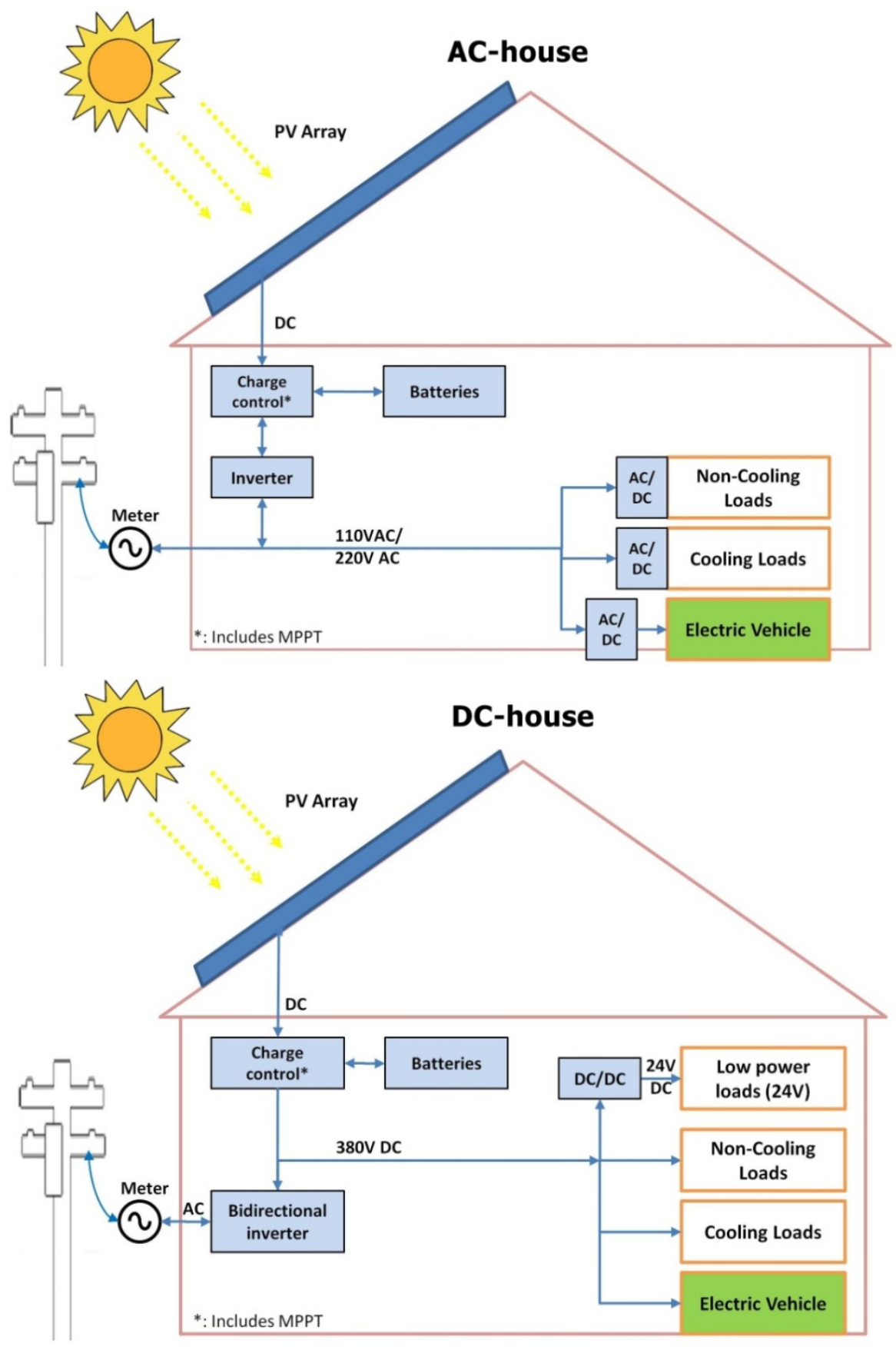

Figure 8. House configurations with storage.

Top: AC-house with storage and optional electric vehicle load. Bottom: DC-house with storage and optional electric vehicle load. Both house inverters are bi-directional, allowing battery charging from the solar system during the day and from the grid at night. 
To identify a reasonable value for the maximum charging capacity of the battery (in kilowatt-hours, $\mathrm{kWh}$ ), the model was run for one city (Sacramento) and a sensitivity analysis was performed to determine how the amount of excess PV power sent to storage varied with battery capacity. The results of this analysis are presented Figure 9. For charging capacities up to about 10kWh a linear relationship exists between the charging capacity and the percentage of excess PV sent to storage. For charging capacities greater than $10 \mathrm{kWh}$, the relationship becomes one of diminishing returns. Therefore, taking into account the results of this analysis, which are consistent with the findings of Mulder et al. (2010) a battery capacity of $10 \mathrm{kWh}$ was assumed. The minimum charging preserved in the battery was taken as $20 \%$ of full capacity $(2 \mathrm{kWh})$, a typical value for deep cycle batteries.

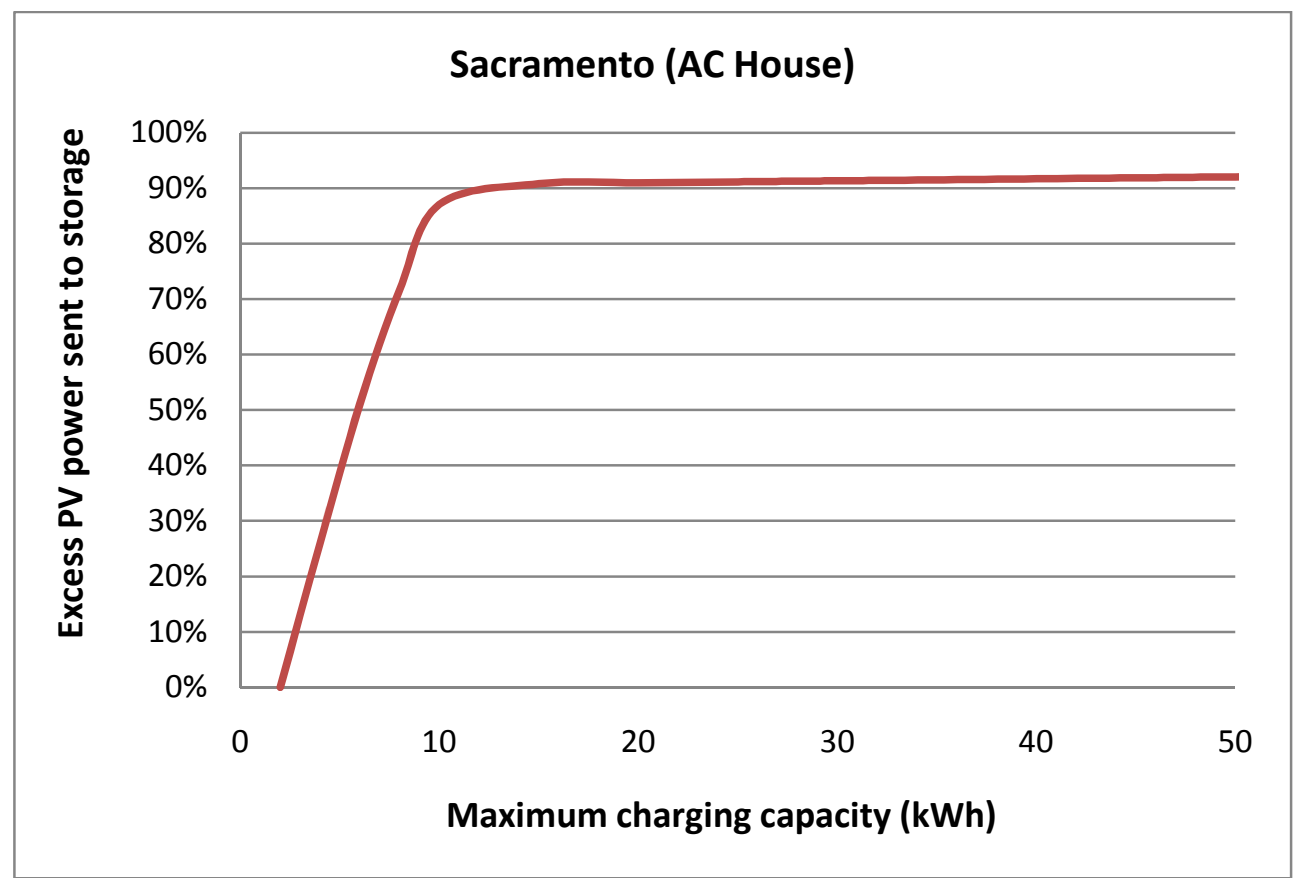

Figure 9. Relationship of maximum battery charging capacity to excess PV. 
In addition, to test if the modeling calculations led to reasonable results, the

model results were analyzed for all 14 cities to determine the percentage of time that the battery was at minimum and maximum capacity, the percentage of PV output not going directly to loads that was sent to the battery and the percentage of excess PV power that would have been sent to the grid in the absence of storage but was sent to storage instead.

The results are shown in Table 7.

Table 7

Storage System Performance in the AC and DC Houses

\begin{tabular}{|c|c|c|c|c|c|c|c|c|c|c|}
\hline \multirow[b]{2}{*}{$\#$} & \multirow[b]{2}{*}{ CITIES } & \multirow{2}{*}{$\begin{array}{l}\text { Cooling } \\
\text { load } \\
\text { fraction }\end{array}$} & \multicolumn{2}{|c|}{$\begin{array}{c}\text { Percent of } \\
\text { time storage } \\
\text { is at } \\
\text { minimum } \\
\text { capacity }\end{array}$} & \multicolumn{2}{|c|}{$\begin{array}{c}\text { Percent of } \\
\text { time storage } \\
\text { is at } \\
\text { maximum } \\
\text { capacity }\end{array}$} & \multicolumn{2}{|c|}{$\begin{array}{c}\text { Percent of } \\
\text { non-coincident } \\
\text { with PV loads } \\
\text { serviced by } \\
\text { storage }\end{array}$} & \multicolumn{2}{|c|}{$\begin{array}{c}\text { Percent of } \\
\text { excess PV } \\
\text { power sent } \\
\text { to storage }\end{array}$} \\
\hline & & & $\mathrm{AC}$ & DC & $\mathbf{A C}$ & DC & $\mathbf{A C}$ & DC & $\mathrm{AC}$ & DC \\
\hline 1 & Phoenix & $66 \%$ & $33 \%$ & $28 \%$ & $18 \%$ & $21 \%$ & $42 \%$ & $46 \%$ & $54 \%$ & $48 \%$ \\
\hline 2 & Tampa & $56 \%$ & $34 \%$ & $27 \%$ & $12 \%$ & $16 \%$ & $57 \%$ & $65 \%$ & $73 \%$ & $65 \%$ \\
\hline 3 & Houston & $48 \%$ & $32 \%$ & $24 \%$ & $13 \%$ & $15 \%$ & $57 \%$ & $66 \%$ & $73 \%$ & $67 \%$ \\
\hline 4 & Fort Worth & $43 \%$ & $30 \%$ & $21 \%$ & $11 \%$ & $13 \%$ & $58 \%$ & $68 \%$ & $74 \%$ & $70 \%$ \\
\hline 5 & Sacramento & $32 \%$ & $32 \%$ & $22 \%$ & $6 \%$ & $9 \%$ & $68 \%$ & $78 \%$ & $87 \%$ & $80 \%$ \\
\hline 6 & Atlanta & $28 \%$ & $25 \%$ & $16 \%$ & $6 \%$ & $9 \%$ & $68 \%$ & $79 \%$ & $87 \%$ & $81 \%$ \\
\hline 7 & Lexington & $17 \%$ & $27 \%$ & $17 \%$ & $6 \%$ & $8 \%$ & $68 \%$ & $80 \%$ & $88 \%$ & $81 \%$ \\
\hline 8 & Medford & $17 \%$ & $34 \%$ & $23 \%$ & $9 \%$ & $10 \%$ & $63 \%$ & $73 \%$ & $81 \%$ & $75 \%$ \\
\hline 9 & Los Angeles & $15 \%$ & $26 \%$ & $14 \%$ & $3 \%$ & $5 \%$ & $74 \%$ & $86 \%$ & $95 \%$ & $88 \%$ \\
\hline 10 & New York & $11 \%$ & $25 \%$ & $15 \%$ & $4 \%$ & $7 \%$ & $72 \%$ & $82 \%$ & $92 \%$ & $84 \%$ \\
\hline 11 & Denver & $10 \%$ & $24 \%$ & $13 \%$ & $5 \%$ & $7 \%$ & $73 \%$ & $85 \%$ & $94 \%$ & $87 \%$ \\
\hline 12 & Helena & $9 \%$ & $28 \%$ & $20 \%$ & $8 \%$ & $11 \%$ & $64 \%$ & $73 \%$ & $82 \%$ & $75 \%$ \\
\hline 13 & Chicago & $8 \%$ & $28 \%$ & $17 \%$ & $7 \%$ & $9 \%$ & $67 \%$ & $77 \%$ & $86 \%$ & $79 \%$ \\
\hline 14 & Seattle & $3 \%$ & $29 \%$ & $24 \%$ & $8 \%$ & $10 \%$ & $60 \%$ & $64 \%$ & $77 \%$ & $67 \%$ \\
\hline \multicolumn{3}{|c|}{ AVERAGES } & $29 \%$ & $20 \%$ & $8 \%$ & $11 \%$ & $64 \%$ & $73 \%$ & $82 \%$ & $75 \%$ \\
\hline \multicolumn{3}{|c|}{ Standard Deviation } & $3 \%$ & $5 \%$ & $4 \%$ & $4 \%$ & $8 \%$ & $11 \%$ & $11 \%$ & $11 \%$ \\
\hline
\end{tabular}


As shown in Table 7, the battery assumptions appear viable for all cities. In none of the cities are the batteries at minimum or maximum capacity for an undue period of time. In addition, the batteries appear highly active, receiving a high percentage of excess PV power and serving a high percentage of the load that is not serviced directly by PV. Thus, all houses with storage systems achieve their primary goal, which is to minimize power coming from the grid and buffering power sent to the grid.

Configurations with load shifting. To test the potential of load shifting to improve direct-DC savings, the impact of shifting the residential cooling load two hours earlier in the day throughout the cooling season was modeled. The cooling load was shifted because (1) cooling dominates residential electricity use in general and particularly in high electricity use areas, and (2) the residential cooling load is skewed toward evening hours, as shown in

Figure 4. Load shifting was limited to two hours because of the limited ability of the system to store "coolth" (with typical home air exchange rates on the order of onehalf an air change per hour). While large shifts could be obtained using dedicated thermal storage technologies (such as chilled water storage), they are cost prohibitive, at least for most residential applications, in the foreseeable future. The house configurations with load shifting do not require any additional power system components apart from the home energy management system, which is assumed to have a negligent effect on the house electricity consumption. 
Configurations with electric vehicle. The EV battery was considered to receive power from the house electric distribution system and not to discharge power to the house loads. As a result, it was modeled as an additional DC-internal load. As shown in Figure 8 , the AC distribution house requires a rectifier and a charge controller, which are not necessary for the DC distribution house.

To estimate the total energy use of the EV per annum, the following assumptions were made:

- The EV battery capacity (in $\mathrm{kWh}$ ) is $24 \mathrm{kWh}$, equal to the battery capacity of the Nissan Leaf (2011).

- Each night, the EV returns to the house charging station at two-thirds (16kWh) of its charging capacity and each morning it is fully charged (at $24 \mathrm{kWh}$ ).

- Charging occurs for 8 hours during the night (between $10 \mathrm{pm}-5 \mathrm{am}$ ) at a rate of $1 \mathrm{kWh} / \mathrm{hr}$. This includes the EV appliance AC/DC converter losses (which is assumed to have $93 \%$ efficiency, equal to the house rectifier) and charge controller losses. Charge controller losses are assumed to be identical for both the AC- and the DC-houses.

Based on these approximations, the total energy use of the $\mathrm{EV}$ is $8 \mathrm{kWh} \times 365$ days $=$ 2,920kWh/yr. It should be noted that the PV array was not resized to accommodate the EV load in the net-zero energy requirement for the AC-house.

Model runs. As mentioned earlier, the model tracks the efficiency losses throughout the residential electricity distribution system and in the AC appliance AC-DC power converters. The model was run as a Microsoft Excel spreadsheet that calculates 
the impact of net-electricity at the electric meter for both houses on a yearly basis for each system configuration. The reported energy savings are the direct-DC savings as a percent of total AC House load for each city. See Appendix C for a description of the modeling calculations for configuration $1 a$-Average residential load. The following model runs were performed:

- Configurations $1 \mathrm{a}$ and $1 \mathrm{~b}$ (average residential load without/with storage) for all cities.

- Configurations $2 \mathrm{a}$ and $2 \mathrm{~b}$ (average residential load shifted without/with storage) for all cities.

- Configurations 3a and 3b (average residential load with EV without/with storage) for one city (Sacramento). This model run was limited to one city because the effect of climate on the previous model runs was not significant.

In addition to the above model runs, sensitivity analyses were conducted to test the effect of partial load conditions and possible future technology improvements. 


\section{Results}

\section{Direct-DC Energy Savings}

This section presents the modeling results for all system configurations. It should be emphasized that the energy savings reported here exclude the appliance efficiency savings (shown in Table 4), which were obtained from switching current appliances to DC-internal appliances. Thus, the model addresses only the direct-DC energy savings (shown with the green arrow in Figure 10).

\section{Current Appliances AC Distribution}

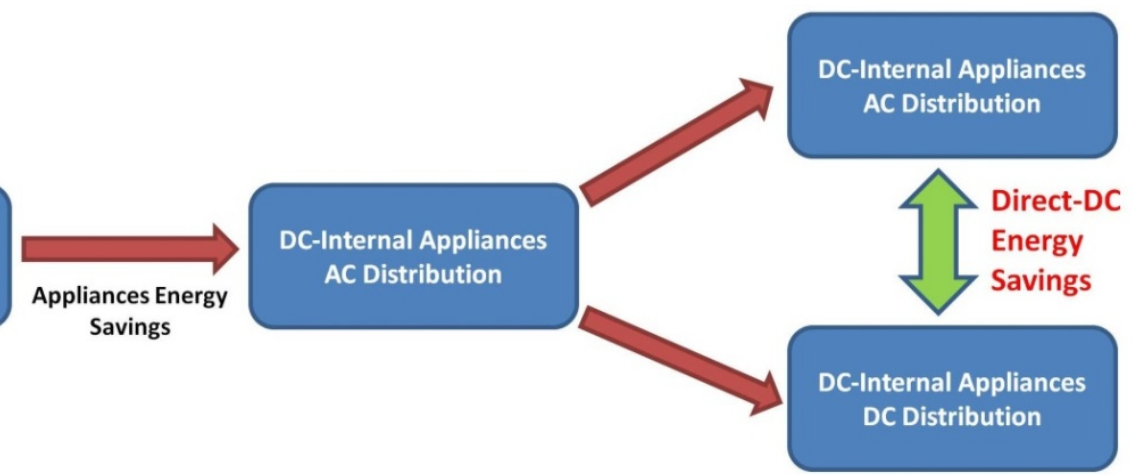

Figure 10. Appliances energy savings versus direct-DC energy savings.

The energy savings estimated by the model do not include energy savings from switching to more efficient, DC-internal appliances.

Average residential load, with and without storage. Table 8 shows the results for system configurations $1 \mathrm{a}$ and $1 \mathrm{~b}$ (Table 6), which modeled the energy use of the ACversus the DC-house, with and without storage, assuming the average annual residential load profile for each of the 14 cities. The cities are ranked by cooling load fraction to test the effect of climate (reflected here by the cooling load fraction). Thus, together these results show the impact on $\mathrm{AC}$ versus DC energy use of both the presence or absence of battery storage and the effect of climate, as described below: 
Direct-DC energy savings. The model predicts that the direct use of DC power will save energy with respect to conventional AC distribution, and that the savings for battery integrated systems are about twice that of non-storage systems. Averaging over all cities, direct-DC saves an estimated $7 \%$ of total (AC-house) electricity use without storage (1a) and $13 \%$ with storage (1b).

Climate effect. The results show only a weak trend between cooling load fraction and direct-DC savings: For the non-storage case, the savings tend to be marginally higher for cities with high cooling load fraction, ranging only from $7 \%$ for low cooling load areas to $8 \%$ for high cooling load areas; whereas, the opposite trend occurs for the storage case, with a savings range from $11 \%$ for high cooling load areas to $13.6 \%$ for low cooling load areas. Thus, climate does not have a strong effect on direct-DC savings. 
Table 8

Direct-DC Savings and Load Serviced Directly by PV

\begin{tabular}{|c|c|c|c|c|c|}
\hline \multirow[b]{2}{*}{ Cities } & \multirow{2}{*}{$\begin{array}{c}\text { Cooling } \\
\text { Load } \\
\text { Fraction }\end{array}$} & \multicolumn{2}{|c|}{$\begin{array}{l}\text { Fraction of load serviced } \\
\text { directly by PV system }\end{array}$} & \multicolumn{2}{|c|}{$\begin{array}{c}\text { Direct-DC savings as percent } \\
\text { of total AC house load }\end{array}$} \\
\hline & & AC-house & DC-house & No-Storage & Storage \\
\hline Phoenix & $66 \%$ & $41 \%$ & $42 \%$ & $7.6 \%$ & $11.0 \%$ \\
\hline Tampa & $56 \%$ & $44 \%$ & $45 \%$ & $8.0 \%$ & $12.2 \%$ \\
\hline Houston & $48 \%$ & $43 \%$ & $44 \%$ & $7.9 \%$ & $12.2 \%$ \\
\hline Fort Worth & $43 \%$ & $40 \%$ & $41 \%$ & $7.6 \%$ & $12.1 \%$ \\
\hline Sacramento & $32 \%$ & $37 \%$ & $38 \%$ & $7.4 \%$ & $13.2 \%$ \\
\hline Atlanta & $28 \%$ & $38 \%$ & $40 \%$ & $7.5 \%$ & $13.0 \%$ \\
\hline Lexington & $17 \%$ & $37 \%$ & $38 \%$ & $7.4 \%$ & $13.1 \%$ \\
\hline Medford & $17 \%$ & $34 \%$ & $35 \%$ & $7.2 \%$ & $12.6 \%$ \\
\hline Los Angeles & $15 \%$ & $36 \%$ & $37 \%$ & $7.3 \%$ & $13.6 \%$ \\
\hline New York & $11 \%$ & $36 \%$ & $37 \%$ & $7.3 \%$ & $13.5 \%$ \\
\hline Denver & $10 \%$ & $34 \%$ & $35 \%$ & $7.2 \%$ & $13.6 \%$ \\
\hline Helena & $9 \%$ & $35 \%$ & $36 \%$ & $7.2 \%$ & $12.8 \%$ \\
\hline Chicago & $8 \%$ & $35 \%$ & $36 \%$ & $7.2 \%$ & $13.1 \%$ \\
\hline Seattle & $3 \%$ & $32 \%$ & $33 \%$ & $7.0 \%$ & $12.8 \%$ \\
\hline All Cities & Averages: & $37 \%$ & $38 \%$ & $7.4 \%$ & $12.8 \%$ \\
\hline
\end{tabular}

System configurations $1 \mathrm{a} \& 1 \mathrm{~b}$ (average residential load without and with storage).

Load fractions directly serviced by the PV system. The average fraction of the load serviced directly by the PV system is both significant and virtually the same for the AC-house and DC-houses, 37\% and 38\%, respectively, as shown in Table 8 (lavender columns). For load shifting (reported next) to significantly improve direct-DC energy savings, the fractions would need to be significantly increased.

Average residential load shifted, with and without storage. Table 9 shows the modeling results for system configurations $2 \mathrm{a}$ and $2 \mathrm{~b}$ (Table 6), in which all cooling loads were shifted two hours earlier than currently indicated by SAM's simulated load 
data. The results are presented as in Table 8. The results show that no significant impact is obtained from the two-hour load shift.

Direct-DC energy savings. The energy savings with and without load shifting are virtually identical. Averaging over all cities, direct-DC saves an estimated $8 \%$ of total (AC-house) electricity use without storage (2a) and $13 \%$ with storage (2b). The negligible improvement in the energy savings of DC over AC is explained by the fact that the load shift increased the fraction of load serviced directly by the PV system only modestly and by about the same amount (by $4 \%$ ) to $41 \%$ and $42 \%$ in both the AC-and the DC-houses, respectively. Again, the inter-city climate differences are minimal and the estimated savings with storage are close to double those without. Therefore, the magnitude of load shifting that might be facilitated by pre-cooling, given the constraints of typical building thermal mass and air exchange rates, has a negligible effect on directDC energy savings. However, it should be noted that larger shifts are possible using dedicated technologies like chilled water storage. 
Table 9

Direct-DC Savings and Load Serviced Directly by PV (Load Shifting)

\begin{tabular}{|c|c|c|c|c|c|}
\hline \multirow[b]{2}{*}{ Cities } & \multirow[b]{2}{*}{$\begin{array}{c}\text { Cooling } \\
\text { Load } \\
\text { Fraction }\end{array}$} & \multicolumn{2}{|c|}{$\begin{array}{l}\text { Fraction of load serviced } \\
\text { directly by PV system }\end{array}$} & \multicolumn{2}{|c|}{$\begin{array}{c}\text { Direct-DC savings as percent } \\
\text { of total AC house load }\end{array}$} \\
\hline & & AC-house & DC-house & No-Storage & Storage \\
\hline Phoenix & $66 \%$ & $48 \%$ & $49 \%$ & $8.3 \%$ & $11.3 \%$ \\
\hline Tampa & $56 \%$ & $50 \%$ & $51 \%$ & $8.5 \%$ & $12.3 \%$ \\
\hline Houston & $48 \%$ & $48 \%$ & $49 \%$ & $8.3 \%$ & $12.3 \%$ \\
\hline Fort Worth & $43 \%$ & $47 \%$ & $48 \%$ & $8.2 \%$ & $12.3 \%$ \\
\hline Sacramento & $32 \%$ & $45 \%$ & $46 \%$ & $8.2 \%$ & $13.1 \%$ \\
\hline Atlanta & $28 \%$ & $44 \%$ & $45 \%$ & $8.0 \%$ & $13.0 \%$ \\
\hline Lexington & $17 \%$ & $41 \%$ & $42 \%$ & $7.8 \%$ & $13.2 \%$ \\
\hline Medford & $17 \%$ & $39 \%$ & $40 \%$ & $7.6 \%$ & $13.1 \%$ \\
\hline Los Angeles & $15 \%$ & $40 \%$ & $40 \%$ & $7.6 \%$ & $13.5 \%$ \\
\hline New York & $11 \%$ & $38 \%$ & $39 \%$ & $7.5 \%$ & $13.5 \%$ \\
\hline Denver & $10 \%$ & $37 \%$ & $38 \%$ & $7.4 \%$ & $13.5 \%$ \\
\hline Helena & $9 \%$ & $37 \%$ & $38 \%$ & $7.4 \%$ & $13.1 \%$ \\
\hline Chicago & $8 \%$ & $37 \%$ & $38 \%$ & $7.4 \%$ & $13.2 \%$ \\
\hline Seattle & $3 \%$ & $33 \%$ & $34 \%$ & $7.1 \%$ & $12.8 \%$ \\
\hline All Cities & Averages: & $41 \%$ & $42 \%$ & $7.8 \%$ & $12.9 \%$ \\
\hline
\end{tabular}

System configurations $2 \mathrm{a} \& 2 \mathrm{~b}$ (average residential load shifted without and with storage)

Average residential load with EV, with and without storage. The model was

run for Sacramento, a city with a cooling load fraction (32\%) that was close to the average of the cooling load fractions for the 14 modeled cities. Figure 11 shows the modeling results for configurations that included an EV (system configurations 3a and $3 \mathrm{~b}$, Table 6), compared to the ones that did not (configurations $1 \mathrm{a}$ and $1 \mathrm{~b}$ ), for Sacramento. 


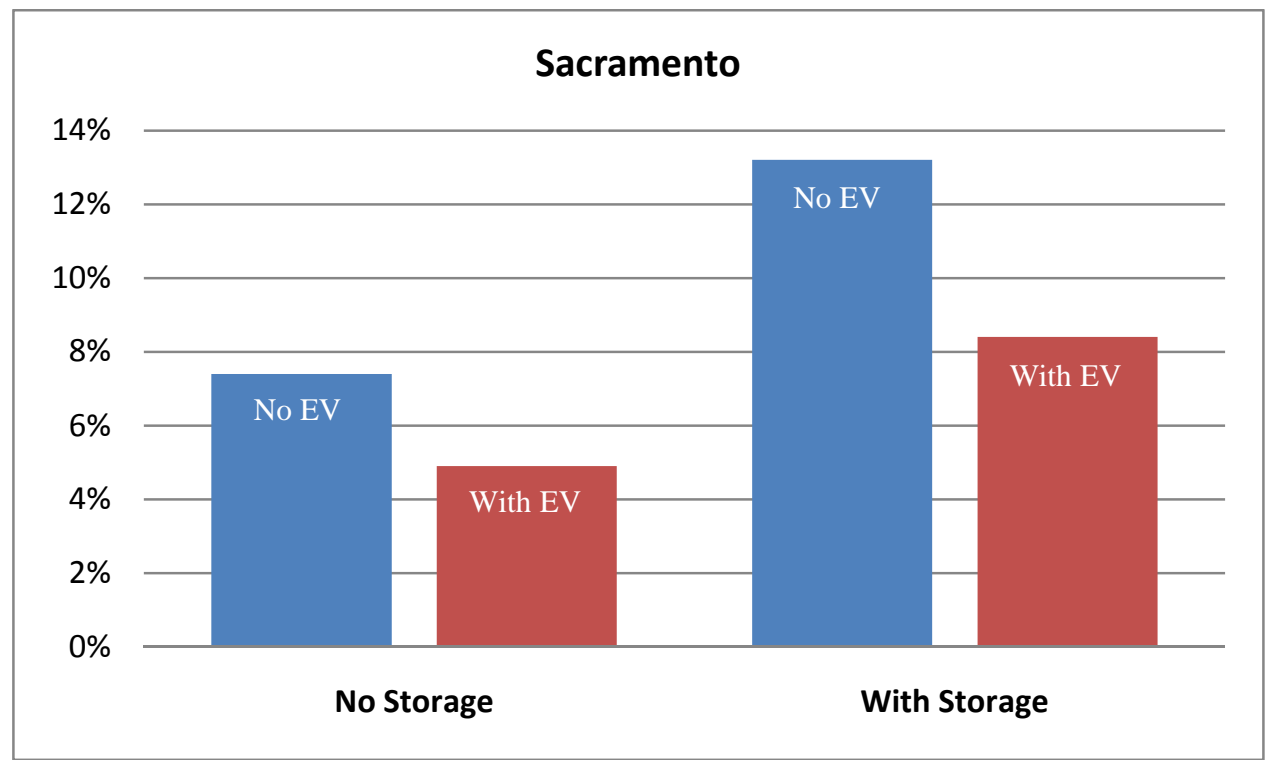

Figure 11. Effect of added EV load on direct-DC savings.

Because the EV is assumed to charge only at night, charging does not add to the absolute energy savings achieved from direct DC. However, the estimated percent savings were reduced from $7.4 \%$ to $4.9 \%$ for the non-storage case and from $13.2 \%$ to $8.4 \%$ for the storage case. The reduction in percent savings is explained by the fact that while the total house load increased significantly, none of that EV load was direct-DC because all charging was assumed to occur at night. The reason for the significant percent decrease in the non-storage house is because the EV represents a significant additional load (consuming 2,920kWh/yr), but none of it is assumed to be direct-DC because the vehicle is assumed to be charged at night.

\section{Sensitivity Analyses}

Technology improvements. As discussed above, direct-DC savings depend inherently on the relative efficiencies of the power system components (inverters, rectifiers, voltage converters, and MPPT) and the appliance converters. Although this 
study uses current high-end efficiencies for the modeling, it is likely that these technologies will improve in the future. Therefore, the model was run for all cities testing the following efficiency improvement scenarios:

1. Improved power system conversion efficiencies. (These products are fairly new on the market, and their efficiencies are expected to improve.):

- House rectifier: $\quad 93 \% \rightarrow 95 \%$

- $\mathrm{DC} / \mathrm{DC}$ converter $(380 \mathrm{~V}-24 \mathrm{~V}): \quad 95 \% \rightarrow 97 \%$

2. Improved appliance AC-DC conversion efficiencies. (Appliance converter efficiencies have been continuously improving. Energy efficiency standards for external power supplies are likely to continue to stimulate improvements both directly and indirectly, in the case of products with internal power supplies.):

- Cooling loads:

$90 \% \rightarrow 95 \%$

- Non-cooling loads:

$87 \% \rightarrow 90 \%$

The results are summarized in Table 10. As expected, if rectifier and DC/DC converter efficiencies improve, direct-DC energy savings increase. On the other hand, if appliance AC-DC conversion efficiencies improve, direct-DC energy savings decrease. Given that such improvements are likely to proceed together, the relative effects are likely to cancel each other out and therefore the model estimates of energy savings will be relatively insensitive to future changes in the efficiencies of power system components and appliance power supplies. 
Table 10

Direct-DC Savings for Improved Power System and Appliance Technologies

\begin{tabular}{lcc}
\hline Efficiencies & $\begin{array}{c}\text { Non-storage } \\
\text { savings }\end{array}$ & $\begin{array}{c}\text { Storage } \\
\text { savings }\end{array}$ \\
\hline Standard Efficiencies & $7.4 \%$ & $12.8 \%$ \\
\hline Improved Power System Conversion Efficiencies & $9.3 \%$ & $13.7 \%$ \\
\hline Improved Appliance AC-DC Conversion Efficiencies & $4.0 \%$ & $9.3 \%$ \\
\hline
\end{tabular}

Variable conversion efficiencies due to load conditions. Power converter efficiencies are considerably lower during part-load conditions than during full-load conditions (see Appendix A). The AC- and DC-house power system components (Figure 5) experience a wide range of operating conditions because both house power demand and PV system output are highly variable. If multiple power system components were used (multiple rectifiers, inverters, etc.) and those that were not needed were turned off, components would operate closer to full-load conditions and have lower overall losses. New utility transformers are emerging on the market, that use this approach and a similar approach is being discussed for power supplies. Future PV power system technologies (and currently developing ones) might follow this approach as well; however, in the foreseeable future power system components will operate at part-load conditions.

To model the magnitude of the impact that part load conditions might have on direct-DC energy savings estimates, part-load efficiencies (for load levels $<20 \%$ of full load) were assigned for the following power system components, as shown in Table 11: 
Table 11

Power System Components Part-load Efficiencies

\begin{tabular}{lcc}
\hline Power system component & Full-load efficiency & Part-load efficiency* \\
\hline AC-house Inverter, includes MPPT & $95 \%$ & $90 \%$ \\
\hline DC-House Rectifier (meter $\rightarrow$ DC) & $93 \%$ & $84 \%$ \\
\hline DC-House Inverter (DC $\rightarrow$ meter) & $97 \%$ & $92 \%$ \\
\hline Charge Controller or MPPT & $98 \%$ & $94 \%$ \\
\hline DC-DC Converter: 380V - 24V & $95 \%$ & $87 \%$ \\
\hline
\end{tabular}

*Part-load efficiencies were derived from the efficiency-load curves available in Appendix A

The above efficiencies were incorporated in the model (system configurations 1a and $1 \mathrm{~b}$, Table 6 - average residential load without and with storage), which was run for the all cities. The results for the average city are shown in Figure 12.

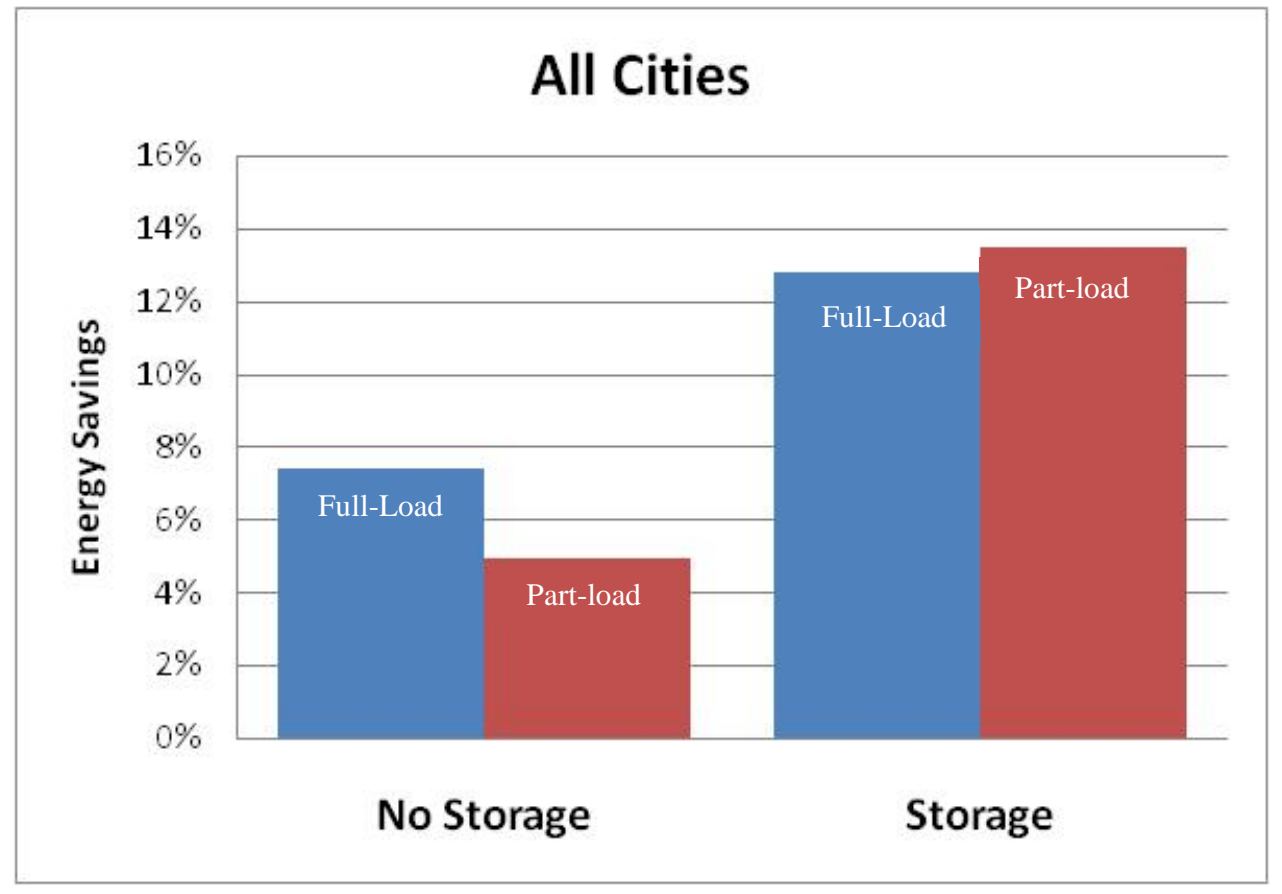

Figure 12. Effects of part-load conditions to direct-DC savings. 
Partial load effects reduce estimates of direct-DC energy savings from $7.4 \%$ to $5.0 \%$ for the non-storage case, but increase them from $12.8 \%$ to $13.5 \%$ for the storage case. The decrease in savings for the non-storage configuration (1a, Table 6 ) is because of the low part-load efficiency of the DC-house rectifier (Figure 5). On the other hand, the increase in savings for the configuration with storage (1b, Table 6$)$ is because of the higher AC-house versus DC-house losses incurred between the batteries and the loads due to the presence of the inverter in the AC-house (Figure 8). 


\section{Conclusions}

\section{Overall Findings}

This paper finds that direct-DC could yield significant energy savings in U.S. houses with net-metered PV systems, if the entire load is constituted of DC powered appliances, especially if those systems incorporate battery storage of sufficient capacity to significantly buffer the grid from PV system fluctuations. Assuming full load efficiencies, for the average city direct-DC saves about $7 \%$ for the non-storage case and about $13 \%$ for the storage case. These estimates do not include the substantial (about $35 \%$ ) energy savings that are obtained by switching the entire load to efficient DCinternal appliances, reflecting a continuation of the current trend.

The energy savings from direct-DC vary relatively little under the wide range of climate conditions represented by U.S. cities distributed throughout the contiguous United States. Not surprisingly, direct-DC has no advantage for the charging of electric vehicle loads, if those loads are charged at night. Also, two-hour shifting of the cooling load only marginally increases the percentage energy savings from the direct use of PV power. For all configurations, the relative power system and appliance conversion efficiencies have the most significant effect on the direct-DC savings. If improvements in appliance conversions efficiencies (power supplies) improve faster than power system component efficiencies, the relative benefits of direct-DC over AC will go down. Moreover, future trends in system component efficiencies are not likely to significantly affect the relative benefits of DC over AC, because some of these improvements favor 
AC distribution while others favor DC distribution. Such improvements do of course reduce overall energy use.

Because today's power system components have significantly lower efficiency under part load conditions, and because all buildings have significantly variable loads, the actual direct-DC energy savings are expected to be different from those based on full load efficiencies. The sensitivity analysis for partial load conditions suggests that partial load conditions would reduce savings for the non-storage case by about $2 \%$ and increase savings by about $1 \%$ for the storage case. Therefore, the overall best estimates for directDC savings are the following:

$$
\begin{gathered}
\text { Non-Storage Savings }=5 \% \\
\text { Storage Savings }=14 \%
\end{gathered}
$$

It is difficult to compare these estimates of energy savings with the work of others because of the different scope of the studies. No other studies of direct-DC energy savings were found that had the same scope or utilized the same assumptions. For example Savage et al. (2010) reported a 25\% energy savings potential, but they assumed today's average power supply efficiency for the AC/DC appliance conversion efficiency rather than best-on-market efficiencies and did not account for different efficiencies for different power supply capacities, as this study did. They also addressed only a subset of the residential load (for example, space cooling was not included) and reported the savings for only a portion of that load. In addition, Baek et al. (2010) reported a 1-3\% direct-DC savings but did not model a net-metered (hybrid energy source) residence and considered only an all AC or an all DC source. 


\section{Discussion}

Energy storage. A potential benefit of electricity storage systems is their ability to buffer the utility grid from power spikes and thus add flexibility to the electric grid, especially in a future scenario with high renewable energy penetration levels. However, because residential loads have little coincidence with peak PV output, electric storage systems need to have very high storage capacities to store all of the excess PV power that is produced during such periods. This was evident in Table 7, where the battery systems (which are assumed to have a 10kWh capacity) were at maximum capacity $10-15 \%$ of the time. If multiple PV systems injected excess PV power to the grid at the same time, this could lead to problems such as damaging transformers in electric substations. Therefore, to avoid the risk of grid damage, a portion of the excess PV power would have to be spilled, that is would not be used either by the grid or by the house loads. Of course, in a high renewable energy penetration scenario, the amount of spilled energy would be significantly higher if energy storage was not implemented. However, note that such spillage could be diverted to unscheduled loads like regional water heating and waste could be reduced.

Electric vehicles. As indicated previously, whether direct-DC holds any efficiency advantage for EV charging depends on whether that charging can he done during the day. In this work, it was assumed that residential vehicle charging occurs at night. In commercial applications however, the load timing might be more advantageous for direct-DC, for example with commuters charging their cars during the day while at work. This could provide a better match between PV system output and EV load. Given 
that electric vehicle "fueling" is cost competitive with gasoline (even with the relatively high cost of solar electricity), because of the far greater efficiency of electric motors compared to gasoline engines, efficient direct-DC vehicle charging in commercial settings is likely to be the most cost effective use of solar electricity associated with building loads. Indeed, given that vehicle charging is probably the single most cost competitive use of PV power, and given the benefits to workers of day-time charging at the workplace, this application provides fertile ground for energy policy innovations.

Proposed future work. The main improvements that could be made to this work include using higher resolution load and PV data that are more representative of actual conditions and calculating the impact on costs accounting for time of day pricing in different regions of the country. The modeling presented here was implemented using simulated average load data at 1-hour increments. A higher resolution model (at 5minute or even 1-minute increments of load data) with individual house load data (or simulated data that resembled actual house load data) could provide more accuracy (and therefore legitimacy) to the calculated direct-DC savings. It is anticipated that if real load data were used in the modeling, the savings would be reduced, because the large load peaks in actual loads would mean that PV system output was less often able to supply the full load under high load conditions. In addition, an investigation of the cost implications associated with direct-DC power distribution, including capital costs and the price of electric power throughout the lifetime of the power systems, is worth pursuing further, but relatively high uncertainties on future prices are likely to persist because DC power systems are not yet on the market. 
Current trends suggest that the transition to a DC-based power future is feasible and may indeed be underway. The energy efficiency imperative along with continued drive toward product quality improvements is driving the adoption of DC-compatible products like electronic lighting, efficient DC motors, ultra-efficient space cooling, and electric heat pumps. The very rapid adoption of building-sited solar power, along with new DC power standards, is already stimulating the entry of DC products to mainstream commercial markets under the EMerge $24 \mathrm{~V}_{\mathrm{DC}}$ and $380 \mathrm{~V}_{\mathrm{DC}}$ Standards. The ease with which energy storage and EV charging can be added to a direct-DC power system will increase the future attraction of direct-DC, and the EV charging standards for DC technology that are currently under development by SAE International will further ease the path to entry. While direct-DC for residential applications will most likely arise as a spin-off of developments for the commercial sector, because of that sector's load having more overlap with PV output and therefore higher energy savings and economic benefits, this thesis clearly illustrates that there are substantial benefits in the residential sector as well, especially in a future with high PV penetration buffered by local energy storage. 


\section{References}

Armstrong. (2011). DC Flexzone grid. Retrieved from

http://www.armstrong.com/commceilingsna/article55189.html

Baek, J., Gab-Su, S., Kyusik, C., Cheol-Woo, P., Hyejin, K., Hyunsu, B., \& Bo, H. C. (2011). DC distribution system design and implementation for green building. Paper presented at the Green Building Power Forum, San Jose, CA.

Barbose, G., Darghouth, N., \& Wiser, R. (2010). Tracking the Sun III: The installed cost of photovoltaics in the U.S. from 1998-2009. (LBNL-4121E). Berkeley, CA: Lawrence Berkeley National Laboratory. Retrieved from http://eetd.lbl.gov/ea/ems/reports/lbnl-4121e.pdf

Bower, W., Whitaker, C., Erdman, W., Behnke, M., \& Fitzgerald, M. (2004).

Performance test protocol for evaluating inverters used in grid-connected photovoltaic systems. Retrieved from http://www.gosolarcalifornia.org/equipment/documents/2004-1122_TEST_PROTOCOL.PDF

Brearly, D. (2010). Distributed PV system optimization: Microinverters, DC-to-DC and two-stage inverters. SolarPro, 3.5, 32-58.

CEC and CPUC. (2011). List of eligible inverters per SB1 guidelines. Retrieved from http://www.gosolarcalifornia.org/equipment/inverters.php

Cetin, E., Yilanci, A., Ozturk, H. K., Colak, M., Kasikci, I., \& Iplikci, S. (2010). A micro-DC power distribution system for a residential application energized by photovoltaic-wind/fuel cell hybrid energy systems. Energy and Buildings, 42(8), 1344-1352. doi: 10.1016/j.enbuild.2010.03.003

Cvetkovic, I., Boroyevich, D., Lee, F. C., Mattavelli, P., Dong, D., Zhang, W.,...Zhou, B. (2011). DC power systems for sustainable buildings. Paper presented at the Green Building Power Forum, San Jose, CA.

Denholm, P., Ela, E., Kirby, E., \& Milligan, M. (2010). The role of energy storage with renewable electricity generation. (NREL/TP-6A2-47187). Golden, CO: National Renewable Energy Laboratory.

Denholm, P., \& Margolis, R. M. (2007). Evaluating the limits of solar photovoltaics (PV) in electric power systems utilizing energy storage and other enabling technologies. Energy Policy, 35(9), 4424-4433. doi: 10.1016/j.enpol.2007.03.004 
Ecos. (2010). Power supplies efficiencies. Retrieved from http://www.80plus.org

EMerge Alliance. (2011). An open industry association. Retrieved from http://emergealliance.org

Engelen, K., Leung Shun, E., Vermeyen, P., Pardon, I., D'Hulst, R., Driesen, J., \& Belmans, R. (2006, November 6-10). The feasibility of small-scale residential DC distribution systems. Paper presented at the IEEE Industrial Electronics, IECON 2006-32nd Annual Conference.

Garbesi, K., Vossos, V., \& Shen, H. (2011). Catalog of DC appliances and power systems. Unpublished manuscript. Berkeley, CA: Lawrence Berkeley National Lab.

George, K. (2006). DC power production, delivery and utilization. [White Paper]. Electric Power Research Institute. Retrieved from http://dcdatacenters.com/publications/epri/epriDCpower_WhitePaper_June2006FI NAL.pdf

Goodnight, J. (2009). Grid down power up. Utility-interactive battery backup system design. SolarPro, 2.2, 68-75.

Hammerstrom, D. J. (2007). AC versus DC distribution systems. Did we get it right? Paper presented at the Power Engineering Society General Meeting, 2007. IEEE.

Hurst, D., \& Wheelock, C. (2009). Plug-in hybrid electric vehicles the global outlook for PHEVs: Business issues, technology issues, key players, and market forecasts. Executive summary. Retrieved from https://www.pikeresearch.com/wpcontent/uploads/2009/07/PHEV-09-Executive-Summary.pdf

International Energy Agency (IEA). (2009). Gadgets and gigawatts. Policies for energy efficient electronics. Paris: OECD/IEA.

Ito, Y., Zhongqing, Y., \& Akagi, H. (2004). DC microgrid based distribution power generation system. Paper presented at the Power Electronics and Motion Control Conference, 2004. IPEMC 2004.

Kakigano, H., Miura, Y., \& Ise, T. (2009). Configuration and control of a DC microgrid for residential houses. Paper presented at the Transmission \& Distribution Conference \& Exposition: Asia and Pacific, 2009. 
Lee, F. C., Boroyevich, D., Mattavelli, P., \& Ngo, K. (2010). Proposal for a miniconsortium on sustainable buildings and nanogrids. Blacksburg, VA: Center for Power Electronic Systems, Virgina Tech.

Lee, P.-W., Lee, Y.-Z., \& Lin, B.-T. (1999, 1999). Power distribution systems for future homes. Paper presented at the IEEE 1999 International Conference on Power Electronics and Drive Systems, Hong Kong.

Malcomb, J. (2010). Who are the leaders in the US solar PV integration market? Retrieved from http://blog.jessemalcomb.com/2010/08/07/who-are-the-leaders-inthe-us-solar-pv-integration-market.aspx

McNichol, T. (2006). AC/DC: The savage tale of the first standards war. San Francisco, CA: Jossey-Bass.

Morningstar Corporation. (2011). Sunsaver MPPT. Retrieved from http://www.morningstarcorp.com/en/sunsavermppt

Mulder, G., Ridder, F. D., \& Six, D. (2010). Electricity storage for grid-connected household dwellings with PV panels. Solar Energy, 84(7), 1284-1293.

North Carolina Solar Center (NCSC) \& Interstate Renewable Energy Council (IREC). (2011). Database of state incentives for renewables and efficiency: Net metering policies summary map. Retrieved from http://www.dsireusa.org/userfiles/image/summarymaps/netmeteringmap.gif

Nextek Power Systems. (2010). Nextek power systems: Product specification sheets. Retrieved from http://www.nextekpower.com/products/product-spec-sheets

NexTek Power Systems. (2011). NPS R1000 maximum power point tracker. Retrieved from http://www.nextekpower.com/support/NPS-R1000-Maximum-Power-PointTracker.pdf

Nilsson, D. (2005). DC distribution systems. Licentiate of Engineering, Chalmers University of Technology, Goteborg. Retrieved from http://webfiles.portal.chalmers.se/et/Lic/NilssonDanielLic.pdf

Nissan USA. (2011). Nissan Leaf FAQs: Technology. Retrieved from http://www.nissanusa.com/leaf-electric-car/faq/list/technology\#/leaf-electriccar/faq/list/technology 
Ornelas, E. (2009). Basics of electric vehicle charging. Retrieved from http://www.sfenvironment.org/downloads/library/SFCCC/ABC\%27s\%20of\%20B attery\%20Charging.pdf

Paajanen, P., Kaipia, T., \& Partanen, J. (2009, June 8-11). DC supply of low-voltage electricity appliances in residential buildings. Paper presented at the CIRED 2009. 20th International Conference on Electricity Distribution, Prague.

Pang, H., Lo, E., \& Pong, B. (2006, November 12-14). DC electrical distribution systems in buildings. Paper presented at the 2nd International Conference on Power Electronics Systems and Applications.

Price, S., \& Margolis, R. M. (2010). 2008 solar technologies market report. U.S. Department of Energy. Retrieved from http://www1.eere.energy.gov/solar/pdfs/46025.pdf

Princeton Power Systems. (2010). GTIB-480-100 Grid-Tied Inverter System. Retrieved from http://www.princetonpower.com/pdfs/spec_gtib-480-100.pdf

Roberts, B. (2008). Photovoltaic solar resource of the United States. Retrieved from http://www.nrel.gov/gis/images/map_pv_national_lo-res.jpg

Sannino, A., Postiglione, G., \& Bollen, M. H. J. (2003). Feasibility of a DC network for commercial facilities. Industry Applications, IEEE Transactions on Industry Applications, 39(5), 1499-1507.

Savage, P., Nordhaus, R. R., \& Jamieson, S. P. (2010). DC microgrids: Benefits and barriers. In REIL (Ed.), From silos to systems: Issues in clean energy and climate change. New Haven, CT: Yale Publications.

Sharp. (2011). Sharp develops intelligent power conditioner that enables electric vehicle batteries to be used as storage batteries for home power. Retrieved from http://sharp-world.com/corporate/news/110222.html

Sherwood, L. (2010). U.S. solar market trends 2009. Interstate Renewable Energy Council. Retrieved from http://irecusa.org/wp-content/uploads/2010/07/IRECSolar-Market-Trends-Report-2010_7-27-10_web1.pdf

SMA. (2010). SUNNY BOY 5000-US / 6000-US / 7000-US / 8000-US. Retrieved from http://download.sma.de/smaprosa/dateien/4752/SUNNYBOY5678DUS103927W.pdf 
Solar Energy Industries Association. (2010). U.S. Solar Market Insight(TM): 2010 year in review (executive summary). Solar Energy Industries Association Retrieved from http://www.energyportal.eu/latest-solar-energy-news/9344-us-solar-marketinsight-report-strong-us-solar-industry-growth-for-first-half-of-2010.html

Star, E. (2010). Energy Star EPS specifications (dataset used to determine Final Draft Version 2.0 Specification Levels). Retrieved from http://www.energystar.gov/index.cfm?c=revisions.eps_spec

Starke, M. R., Tolbert, L. M., \& Ozpineci, B. (2008, April 21-24). AC vs. DC distribution: A loss comparison. Paper presented at the Transmission and Distribution Conference and Exposition, 2008. T\&\#x00026;D. IEEE/PES.

Stevens, J. W., \& Corey, G. P. (1996). A study of lead-acid battery efficiency near top-ofcharge and the impact on PV system design. Paper presented at the Photovoltaic Specialists Conference, Washington, DC.

U.S. Department of Energy (DOE). (2010). Fueleconomy.gov: New \& upcoming electric vehicles. Retrieved from http://www.fueleconomy.gov/feg/evnews.shtml

U.S. Energy Information Administration (EIA). (2009). The National Energy Modeling System: An overview. Retrieved from http://www.eia.doe.gov/oiaf/aeo/overview

U.S. Energy Information Administration (EIA). (2010). Solar photovoltaic cell/module manufacturing activities. Retrieved from

http://www.eia.doe.gov/cneaf/solar.renewables/page/solarphotv/solarpv.html

U.S. Energy Information Administration (EIA). (2011). U.S. residential electricity consumption by end use. Retrieved from

http://www.eia.doe.gov/tools/faqs/faq.cfm?id=96\&t=3

Ton, M., Fortenbery, B., \& Tschudi, W. (2007). DC power for improved data center efficiency. Berkeley, CA: Lawrence Berkeley National Laboratory. Retrieved from http://hightech.lbl.gov/documents/DATA_CENTERS/DCDemoFinalReport.pdf

Zabalawi, S. A., Mandic, G., \& Nasiri, A. (2008, November 10-13). Utilizing energy storage with $P V$ for residential and commercial use. Paper presented at the Industrial Electronics, 2008. IECON 2008. 34th Annual Conference of IEEE. 


\section{Appendix A: AC and DC House Power System Components}

This appendix describes the power system components included in the modeling of the $\mathrm{AC}$ and $\mathrm{DC}$ houses, specifically all power system components downstream of the PV array. Each entry indicates whether the component is used for the AC or the DC house. The primary purpose is to explain the energy efficiency assumptions used in the modeling and certain decisions about component configurations. PV-power systems for AC-distribution houses are now commonplace, therefore data on such systems are widely available. The modeling assumes efficiencies that represent the high end of the current market. Because the DC-house power system is hypothetical, the assumed characteristics of its components are based on similar products currently on the market but used for other purposes, and on extensive discussion with industry experts involved in the design and manufacture of the new power supplies for DC data centers and other power system components. The final values were also vetted with members of the EMerge Alliance technical committees for the $24 \mathrm{~V}_{\mathrm{DC}}$ and $380 \mathrm{~V}_{\mathrm{DC}}$ standards at the January 2001 meeting of the Green Building Power Forum in San Jose, California.

\section{Inverter without Battery Backup (AC-House)}

Description. Grid-interactive (also known as grid-tie) inverters convert DC coming from the PV array into AC synchronous with the grid. Residential PV systems generally have a single central inverter that converts the entire array's DC power to AC, although the relatively new micro-inverter technology that converts the output of each PV 
module to AC is increasing in usage. This section addresses central inverters because they provide an architecture analogous to the DC-House.

To maximize PV system efficiency, modern grid-interactive inverters include maximum power point tracking (MPPT), described below. Therefore, the efficiencies quoted for these systems include the efficiency losses of the MPPT.

Efficiency. Typical full-load efficiencies of grid-interactive inverters range at 94$97 \%$ while some manufacturers have reported peak efficiencies of more than $98 \%$. However, the AC-house inverter peak efficiency used in the modeling is $95 \%$ based on industry expert input. The efficiency curve of the SMA America SB7000US (7kW) inverter, shown in Figure A1 reveals how efficiencies plummet at very low loads ${ }^{5}$.

\footnotetext{
${ }^{5}$ The California Energy Commission (CEC) has established the weighted efficiency as a more appropriate inverter efficiency metric. The weighted efficiency corresponds to the weighted average efficiency for various inverter input power points, thus accounting for both full load and part load conditions (Bower, Whitaker, Erdman, Behnke, \& Fitzgerald, 2004). Weighted efficiencies are generally about 1-2\% lower than manufacturer peak efficiencies. According to the CEC's list of eligible inverters for the California Solar Initiative, grid-interactive inverter weighted efficiencies with capacities up to $10 \mathrm{~kW}$ range between $84.5 \%$ and $98 \%$ (CEC and CPUC, 2011).
} 


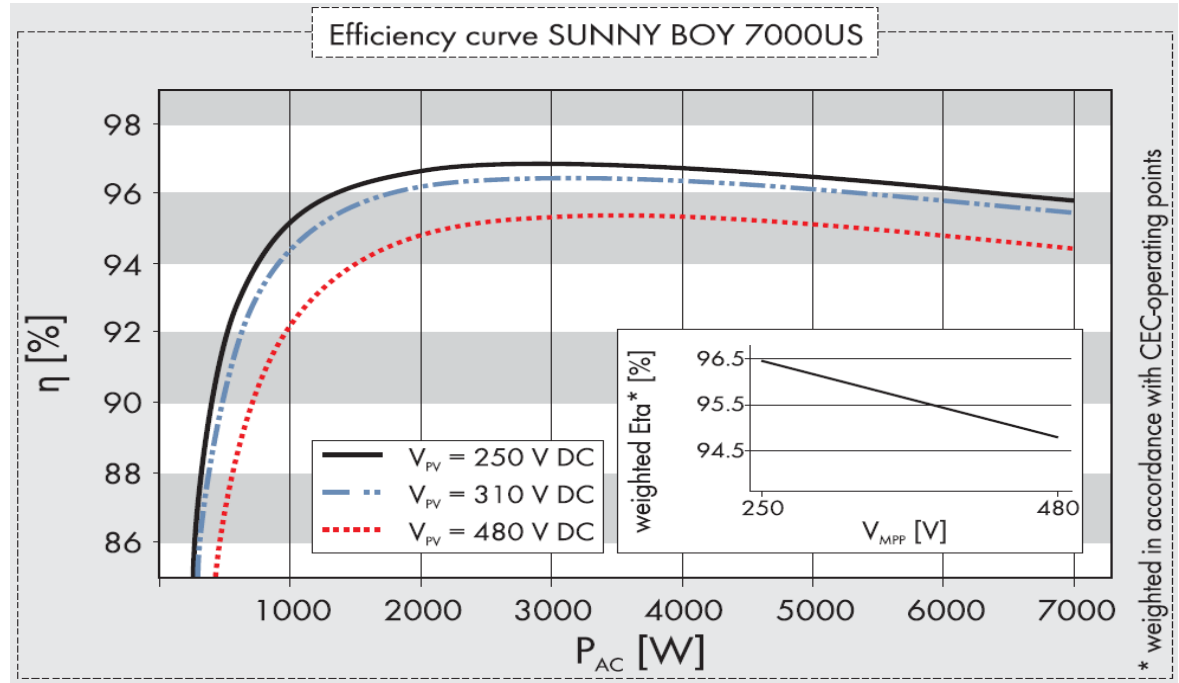

Figure A1. Grid-interactive inverter efficiency curve.

SMA inverter efficiency curve for the SMA Sunny Boy 7000US string inverter (with multiple MPPTs). The efficiency peaks after 30\% load to 96-97\%. Part-load efficiency (below 1000W power capacity) ranges between 86 and 95\%. Reproduced with permission from SMA (SMA, 2010).

\section{Inverter with Battery Backup (AC-House)}

Description. Inverters with battery backup convert DC power coming from the battery, or directly from the PV array, to AC power, which is sent to the loads or to the grid for net-metering. These devices differ in an important way from their non-storage counterparts: They also have a built-in rectifier to convert AC grid-power to DC, as required for battery charging, and would be better described as bi-directional inverters. These inverters manage power flows to and from the battery, but the batteries are external to the device. However, unlike most inverters without battery backup, battery backup inverters do not include MPPT (Goodnight, 2009), as this function is performed by an upstream-located charge controller (see Figure 8). There are far fewer models of battery backup inverters on the market than there are non-storage inverters. 
Efficiency. Efficiencies of inverters with battery backup are generally lower than their non-battery counterparts. Outback Power offers models with weighted efficiencies of $91 \%$. Princeton Power Systems recently developed a 100kW inverter with battery back-up with a 98\% peak efficiency and a 94.5\% weighted efficiency (Princeton Power Systems, 2010).

\section{Bi-directional Inverter/Converter (DC-House)}

Although bidirectional inverters designed for direct-DC power systems are not on the market, in fact, the battery-storage inverter described above is a virtually identical device. It serves to both rectify (AC-DC) power from the grid to the building distribution system and invert (DC-AC) excess power from the PV system or the battery to the grid. The only possible difference between the existing device and one designed for the DC-house modeled here is the requirement in the DC-house that the DC output be at $380 \mathrm{~V}$.

\section{MPPT (DC-House)}

Description. An MPPT is a high efficiency DC-to-DC converter that produces a constant output voltage required by the load and adjusts the apparent load characteristics seen by the PV array to force it to operate at the maximum possible power output. Because the voltage and current supplied by the PV system depend on ambient conditions, the DC power from the array must be conditioned to provide appropriate power quality for the load. MPPTs are usually included in grid-tie inverters without battery backup and in modern charge controllers. 
Currently there is only one such centralized MPPT emerging on the market.

Nextek Power Systems has produced a 1kW MPPT for DC power distribution in commercial lighting applications (NexTek Power Systems, 2011) with a reported 98\%

efficiency. Substantiating this high efficiency are data on MPPTs designed to operate on individual modules. These devices, called DC-to-DC optimizers, track the array's maximum power point at the module level.

Efficiency. Table A1 shows power characteristics and efficiencies of DC-to-DC optimizer models. As can be seen, MPPT efficiencies range between $97.5 \%$ and $99.5 \%$. Table A1

DC-DC Optimizers, Their Power Characteristics and Peak Efficiencies

\begin{tabular}{llcccc}
\hline Manufacturer & Model & $\begin{array}{c}\text { Input } \\
\text { Power } \\
(\mathbf{W})\end{array}$ & $\begin{array}{c}\text { Max } \\
\text { Input } \\
\text { Voltage } \\
(\mathbf{V})\end{array}$ & $\begin{array}{c}\text { Nominal } \\
\text { Output } \\
\text { Voltage (V) }\end{array}$ & $\begin{array}{c}\text { Peak } \\
\text { Efficiency } \\
(\%)\end{array}$ \\
\hline eIQ energy & Vboost 250 & 250 & 50 & $250-350$ & 98.0 \\
$\begin{array}{l}\text { National } \\
\text { Semiconductor }\end{array}$ & SM1230 & 230 & 100 & 89 & 98.5 \\
$\begin{array}{l}\text { Tigo Energy } \\
\text { Tigo Energy }\end{array}$ & $\begin{array}{l}\text { MM-EP35 } \\
\text { MM- }\end{array}$ & 200 & 55 & 375 & 97.5 \\
Xandex & $\begin{array}{l}\text { ES170 } \\
\text { SunMizer }\end{array}$ & 350 & 170 & variable & 99.6 \\
\hline
\end{tabular}

Data Source: SolarPro magazine (Brearly, 2010)

\section{Charge Controller (AC and DC house)}

Description. Charge controllers are used in battery back-up systems to regulate the current sent to, or coming from, the battery. Modern charge controllers include MPPT . The charge controllers for the AC- and DC-house are assumed to be identical in the modeling. 
Efficiency. Typical efficiencies of high-end charge controllers with MPPT range from 97-99\%. Figure A2 shows the efficiency-load curve of the Morningstar SunSaver charge controller, which has a peak efficiency of $97.5 \%$.

SS-MPPT Efficiency (12 Volts)

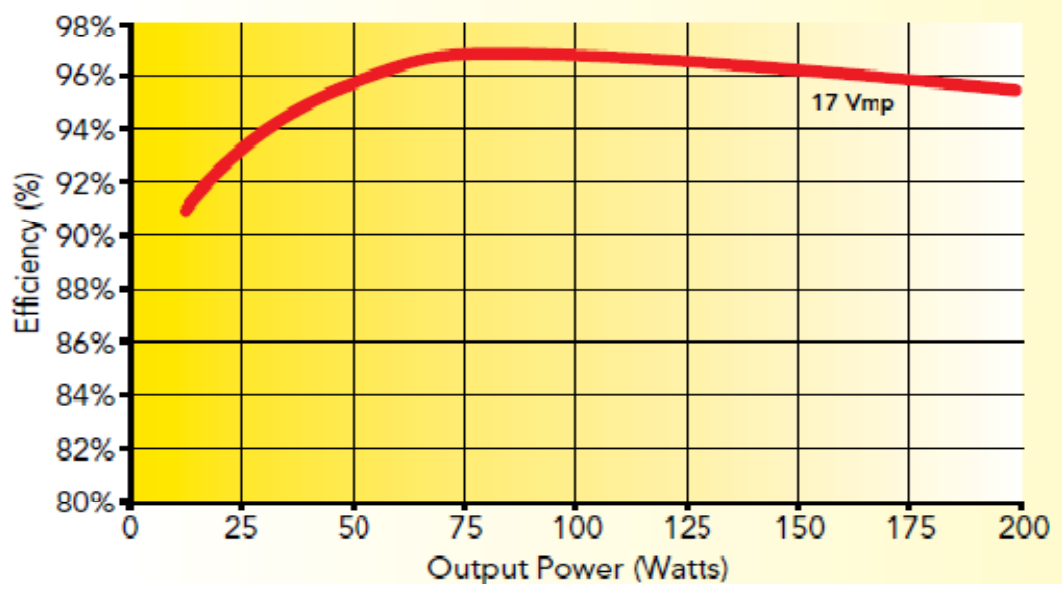

Figure A2. Charge controller efficiency curve.

Efficiency curve of the MorningStar SunSaver charge controller with MPPT. Part load efficiency (below $30 \mathrm{~W}$ output power) is about 90-94\%. Reproduced with permission from Morningstar Corporation (Morningstar Corporation, 2011).

\section{DC/DC Converter (DC-house)}

Description. DC-DC converters are solid-state devices that convert DC power from one voltage level to another. They are widely used in low-power, low voltage applications and are found in appliances with electronic circuits. The DC-to-DC converter envisioned for the DC-house is a high-power converter $(1-5 \mathrm{~kW})$ that requires an input voltage of $380 \mathrm{~V}_{\mathrm{DC}}$ and output of $24 \mathrm{~V}_{\mathrm{DC}}$. Because this converter ties directly to the loads, it is likely to need isolation from the ground, though the relevant standards have not yet been established. This DC-DC converter does not exist yet specifically for residential applications, but is currently in the research and design stage. 
Efficiency. Step-down converters are highly efficient electronic devices with efficiencies that typically reach 95\%. Figure A3 shows the efficiency curves of an existing 700W AC power supply that has been modified for DC input. According to power supply manufacturers, it should be possible to produce more efficient DC-DC converters now. As shown in Figure A3, the power supply is about 2\% more efficient with DC power input $\left(400 \mathrm{~V}_{\mathrm{DC}}\right.$ narrow range) than with $\mathrm{AC}$ power input $\left(220 \mathrm{~V}_{\mathrm{AC}}\right)$. Highend AC power supplies can achieve efficiencies that exceed $92-93 \%$. Thus, it is assumed, with the concurrence of industry experts, that DC power supplies can reach efficiencies of $94-95 \%$ at the high end.

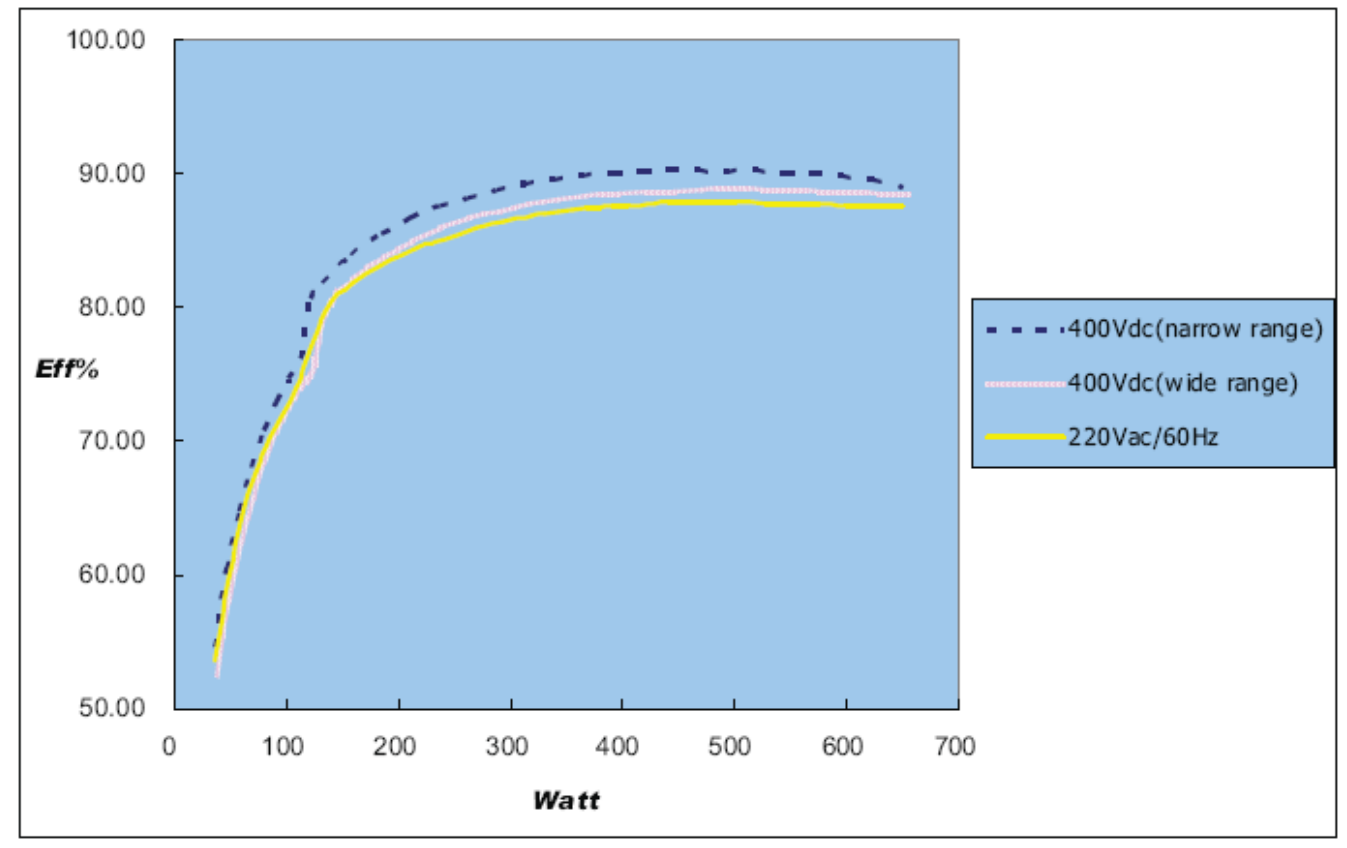

Figure A3. DC power supply efficiency curve.

The power supply's peak efficiency with DC power input (narrow range $400 \mathrm{~V}_{\mathrm{DC}}$ ) is $2 \%$ higher than with AC power input $\left(220 \mathrm{~V}_{\mathrm{AC}}\right)$. Data Source: (T. Lai, personal communication, November 10, 2010). Reproduced with permission from T. Lai. 


\section{Appendix B: Efficient DC-Compatible Load}

(Cooling loads are shaded, non-cooling loads are not shaded. The table is sorted by ACDC conversion efficiency)

\begin{tabular}{|c|c|c|c|c|}
\hline Appliance & $\begin{array}{l}\mathrm{kWh} / \mathrm{yr} \\
\text { in } 2010\end{array}$ & $\begin{array}{c}\text { Assumed Replacement } \\
\text { Technology }\end{array}$ & $\begin{array}{l}\text { Energy } \\
\text { Savings }\end{array}$ & $\begin{array}{l}\text { AC-DC } \\
\text { Conv.Eff }\end{array}$ \\
\hline $\begin{array}{l}\text { Central Air Conditioners } \\
\text { (SEER) }\end{array}$ & 1328 & $\begin{array}{l}\text { DC motor with variable speed } \\
\text { compressor and fans }\end{array}$ & $47 \%$ & $89 \%$ \\
\hline $\begin{array}{l}\text { Room Air Conditioners } \\
\text { (EER) }\end{array}$ & 235 & $\begin{array}{l}\text { DC motor with variable speed } \\
\text { compressor and fans }\end{array}$ & $34 \%$ & $89 \%$ \\
\hline $\begin{array}{l}\text { Electric Heat Pumps } \\
\text { (SEER) AC }\end{array}$ & 355 & unchanged & $0 \%$ & $88 \%$ \\
\hline $\begin{array}{l}\text { Geothermal Heat Pumps } \\
\text { for AC }\end{array}$ & 10 & unchanged & $0 \%$ & $88 \%$ \\
\hline Electric Clothes Dryers & 677 & heat pump & $50 \%$ & $89 \%$ \\
\hline $\begin{array}{l}\text { Electric Secondary } \\
\text { Space Heaters }\end{array}$ & 68 & unchanged & $0 \%$ & $89 \%$ \\
\hline Dishwashers & 232 & controls and DC compatible motor & $51 \%$ & $88 \%$ \\
\hline $\begin{array}{l}\text { Electric Water Heaters } \\
\text { (EF) }\end{array}$ & 1128 & heat pump & $50 \%$ & $88 \%$ \\
\hline $\begin{array}{l}\text { Other Electric Space } \\
\text { Heaters }\end{array}$ & 463 & heat pump & $50 \%$ & $88 \%$ \\
\hline Spas & 72 & heat pump & $50 \%$ & $88 \%$ \\
\hline $\begin{array}{l}\text { Electric Cooking } \\
\text { Equipments 5/ }\end{array}$ & 273 & Induction cooktops & $12 \%$ & $88 \%$ \\
\hline $\begin{array}{l}\text { Electric Heat Pumps } \\
\text { (HSPF) for Heating }\end{array}$ & 185 & unchanged & $0 \%$ & $88 \%$ \\
\hline $\begin{array}{l}\text { Geothermal Heat } \\
\text { Pumps }\end{array}$ & 7 & unchanged & $0 \%$ & $88 \%$ \\
\hline Solar Water Heaters & 3 & unchanged & $0 \%$ & $88 \%$ \\
\hline $\begin{array}{l}\text { Refrigerators (kWh per } \\
\text { year } 6 / \text { ) }\end{array}$ & 930 & $\begin{array}{l}\text { assuming } 85 \% \text { standard-size } \\
\text { @ 587kWh AEU has EURF } 0.49 \\
\text { and } 15 \% \text { compact @ } 331 \mathrm{kWh} \text { AEU } \\
\text { has EURF } 0.25\end{array}$ & $53 \%$ & $87 \%$ \\
\hline $\begin{array}{l}\text { Freezers (kWh per year } \\
6 /)\end{array}$ & 199 & $\begin{array}{l}\text { assuming } 80 \% \text { standard-size } \\
@ 565 \mathrm{kWh} \text { AEU has EURF } 0.47 \\
\text { and } 20 \% \text { compact @ } 246 \mathrm{kWh} \text { AEU } \\
\text { has EURF } 0.48\end{array}$ & $53 \%$ & $87 \%$ \\
\hline $\begin{array}{l}\text { Furnace Fans and } \\
\text { Boiler Circulation } \\
\text { Pumps }\end{array}$ & 366 & Brushless DCPM variable speed & $30 \%$ & $87 \%$ \\
\hline Ceiling Fans & 158 & $\begin{array}{l}\text { Brushless DCPM variable speed } \\
\text { motor }\end{array}$ & $30 \%$ & $87 \%$ \\
\hline Clothes Washers & 83 & $\begin{array}{l}\text { Brushless DCPM variable speed } \\
\text { motor }\end{array}$ & $30 \%$ & $87 \%$ \\
\hline Electric Other & 1468 & unchanged & $0 \%$ & $87 \%$ \\
\hline
\end{tabular}




\begin{tabular}{|c|c|c|c|c|}
\hline Appliance & $\begin{array}{l}\mathrm{kWh} / \mathrm{yr} \\
\text { in } 2010\end{array}$ & $\begin{array}{l}\text { Assumed Replacement } \\
\text { Technology }\end{array}$ & $\begin{array}{l}\text { Energy } \\
\text { Savings }\end{array}$ & $\begin{array}{l}\text { AC-DC } \\
\text { Conv.Eff }\end{array}$ \\
\hline Microwave Ovens & 114 & unchanged & $0 \%$ & $87 \%$ \\
\hline Coffee Makers & 36 & unchanged & $0 \%$ & $87 \%$ \\
\hline $\begin{array}{l}\text { Color Televisions and } \\
\text { Set-Top Boxes }\end{array}$ & 938 & unchanged & $0 \%$ & $85 \%$ \\
\hline Security Systems & 17 & unchanged & $0 \%$ & $83 \%$ \\
\hline Lighting-Incandescent & 1370 & $\begin{array}{l}\text { 14LPW goes to CFL (electronic } \\
\text { ballast) @52LPW }\end{array}$ & $73 \%$ & $82 \%$ \\
\hline Lighting-Reflector & 216 & $\begin{array}{l}\text { 15LPW goes to CFL (electronic } \\
\text { ballast) @52LPW }\end{array}$ & $71 \%$ & $82 \%$ \\
\hline Lighting-Torchiere & 89 & $\begin{array}{l}\text { assuming } 80 \% \text { incandescent } \\
\text { @14LPW goes to CFL @ 52LPW } \\
\text { and 20\% CFL stays the same }\end{array}$ & $69 \%$ & $82 \%$ \\
\hline Lighting-Fluorescent & 148 & $\begin{array}{l}\text { assuming 10\% linear @83LPW } \\
\text { goes to 100LPW and 90\% CFL } \\
\text { @52LPW stays the same }\end{array}$ & $1 \%$ & $82 \%$ \\
\hline $\begin{array}{l}\text { Personal Computers } \\
\text { and Related Equipment }\end{array}$ & 473 & unchanged & $0 \%$ & $80 \%$ \\
\hline $\begin{array}{l}\text { Rechargeable } \\
\text { Electronics }\end{array}$ & 78 & unchanged & $0 \%$ & $80 \%$ \\
\hline Home Audio & 100 & unchanged & $0 \%$ & $79 \%$ \\
\hline DVDs/VCRs & 217 & unchanged & $0 \%$ & $69 \%$ \\
\hline
\end{tabular}

Source: (Garbesi et al., 2011) 
Appendix C: Modeling Calculations for Average Residential Load

\begin{tabular}{|c|c|c|c|c|c|c|c|c|c|c|c|c|c|c|c|c|c|c|c|c|}
\hline \multicolumn{3}{|c|}{ Column \# } & D & $\mathrm{E}$ & $\mathrm{F}$ & G & $\mathrm{H}$ & 1 & J & K & L & M & $\mathrm{N}$ & 0 & $\mathrm{P}$ & $\mathrm{Q}$ & $\mathrm{R}$ & $\mathrm{S}$ & $\mathrm{T}$ & U \\
\hline \multicolumn{3}{|c|}{$\begin{array}{c}\text { Total Yearly Energy } \\
\text { (kWh) }\end{array}$} & 1389 & 7164 & 1214 & 771 & 3997 & 4767 & 5018 & 1719 & 3299 & 3134 & 3134 & 692 & 3574 & 4266 & 1532 & 3487 & 2973 & 3314 \\
\hline \multicolumn{3}{|c|}{$\begin{array}{c}\text { House } \\
\text { Configuration } \\
\end{array}$} & $\mathrm{AC}$ & $A C$ & $\mathrm{AC}$ & $\mathrm{AC}$ & $A C$ & $A C$ & $A C$ & $A C$ & $\mathrm{AC}$ & $A C$ & $A C$ & DC & DC & DC & DC & $\mathrm{DC}$ & DC & DC \\
\hline$\stackrel{3}{\stackrel{3}{5}}$ & $\underset{\Perp}{\rightleftharpoons}$ & $\underset{\mathscr{T}}{\stackrel{T}{g}}$ & 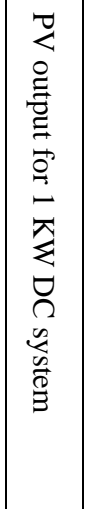 & 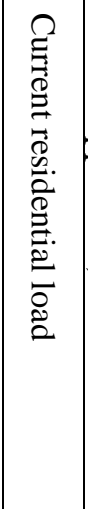 & 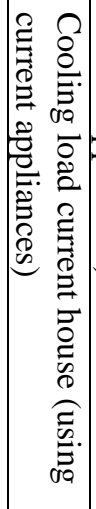 & 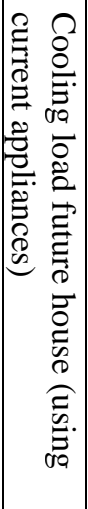 & 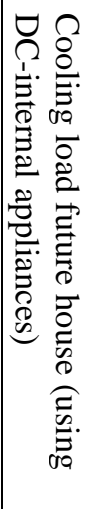 & 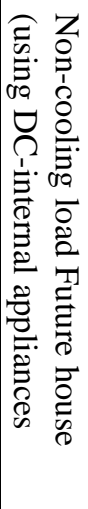 & 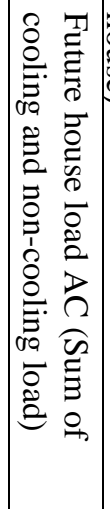 & 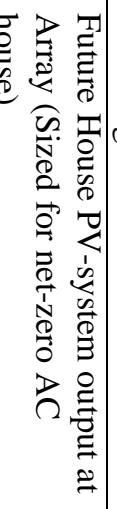 & 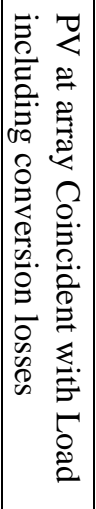 & 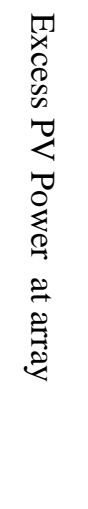 & 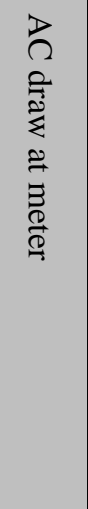 & 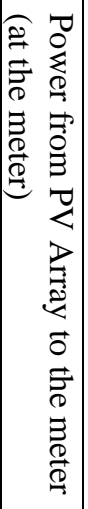 & 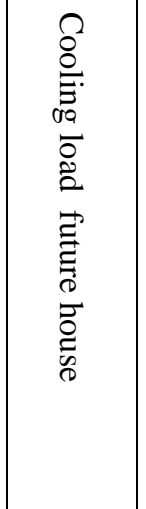 & 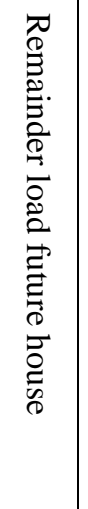 & 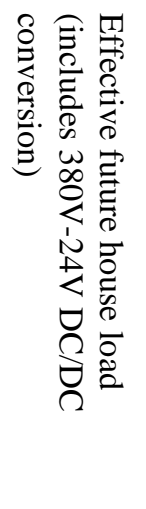 & 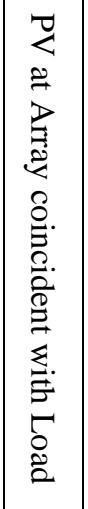 & 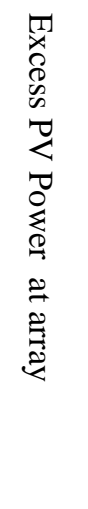 & 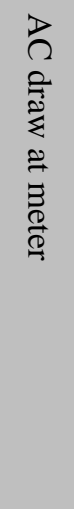 \\
\hline & & & 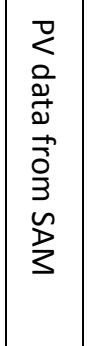 & 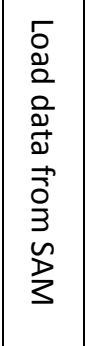 & 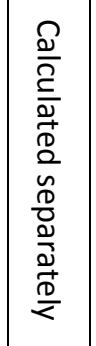 & 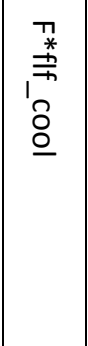 & 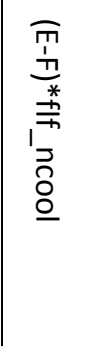 & $\begin{array}{l}I \\
\stackrel{+}{a}\end{array}$ & 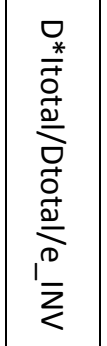 & 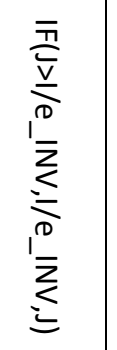 & $\stackrel{\grave{1}}{\lambda}$ & $\begin{array}{l}\frac{\bar{T}}{\lambda} \\
D^{*} \\
\frac{1}{\Sigma}\end{array}$ & $i^{D^{*}}$ & 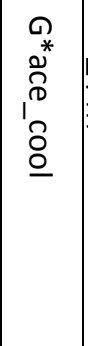 & 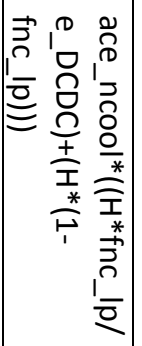 & $\begin{array}{l}0 \\
+ \\
0\end{array}$ & 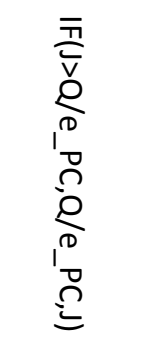 & ד্ & 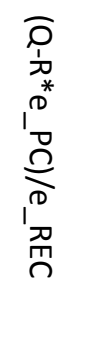 & 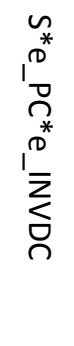 \\
\hline
\end{tabular}

Note: The percent energy savings of the DC-house configuration versus the AC-house configuration are calculated by the ratio of the AC draw at the meter of the AC-house versus the DC-house. 